\title{
Groundwater Evolution, Hydrochemical Facies and Quality Evaluation for Irrigation Use in Akure, Ondo State, Nigeria
}

\section{Olumuyiwa Olusola Falowo*, Moses Bamidele Amodu, Victor Oluwasegunfunmi, Adekunle Aliu, Moses Philip Otuaga}

Department of Civil Engineering Technology, Rufus Giwa Polytechnic, Owo, Ondo State, Nigeria

Email: *solageo@yahoo.co.uk

How to cite this paper: Falowo, O. O., Amodu, M. B., Oluwasegunfunmi, V., Aliu, A., \& Otuaga, M. P. (2019). Groundwater Evolution, Hydrochemical Facies and Quality Evaluation for Irrigation Use in Akure, Ondo State, Nigeria. Journal of Geoscience and Environment Protection, 7, 118-140.

https://doi.org/10.4236/gep.2019.78009

Received: June 26, 2019

Accepted: August 16, 2019

Published: August 19, 2019

Copyright $\odot 2019$ by author(s) and Scientific Research Publishing Inc. This work is licensed under the Creative Commons Attribution International License (CC BY 4.0).

http://creativecommons.org/licenses/by/4.0/

\begin{abstract}
Hydrochemical facies, groundwater evolution, and physicochemical reactions between soil or rock and water are of considerable importance when evaluating or predicting the nature of anthropogenic impacts on groundwater quality. In this respect a total of 67 ground water samples were collected randomly in Akure, southwestern, Nigeria from hand pump/dug wells and analyzed for major cations and anions. The domination of cations and anions was in the order of $\mathrm{Ca}^{2+}>\mathrm{K}^{+}>\mathrm{Na}^{+}>\mathrm{Mg}^{2+}$ and $\mathrm{HCO}_{3}^{-}>\mathrm{Cl}^{-}>\mathrm{SO}_{4}^{2-}>\mathrm{NO}_{3}^{-}$respectively. The $\mathrm{pH}$ and $\mathrm{Eh}$ of the water samples show an acidic condition, with low salinity hazard (generally less than $250 \mu \mathrm{S} / \mathrm{cm}$ ). The Piper classification for hydrogeochemical facies indicates carbonate hardness (secondary alkalinity) exceeds $50 \%$ that is by alkaline earths and weak acids, with $\mathrm{Ca}^{2+}+\mathrm{Mg}^{2+}+$ $\mathrm{HCO}_{3}^{-}$water-type. This also suggests a meteoric origin of water quality caused by rock-water interaction. The ratio of $\mathrm{HCO}_{3}^{-}$and $\mathrm{Cl}^{-}$is greater than 1 and implies recharge area or upper water flow course of carbonate rocks (interaction of water with aquifer material). The $\mathrm{Na}^{+}: \mathrm{Cl}^{-}$is less than 0.7 signifying loss of $\mathrm{Na}^{+}$through precipitation of evaporating water; the water is $\mathrm{Ca}^{2+}$ rich and $\mathrm{Na}^{+}$depleted with $\mathrm{Mg}^{2+}: \mathrm{Ca}^{2+}$ less than 0.5 and $\mathrm{Na}^{+}: \mathrm{K}^{+}$less than 15. The $\mathrm{Na}^{+}: \mathrm{Ca}^{2+}(<1)$ indicates reverse ionic exchange. The $\mathrm{Ca}^{2+}: \mathrm{SO}_{4}^{2-}+\mathrm{HCO}_{3}^{-}$for the samples is less than 1.0 suggestive of flow of water through the normal hydrological cycle. The calculated range of values of sodium absorption ratio (1.89 - 26.42), permeability index (42.67 - 170.24), residue sodium carbonate (-1 to 5$)$, magnesium ratio (4 - 53), Kelly ratio (0.04 - 0.84$)$, percent sodium (0.41 - 3.45) suggest good water suitable for irrigation purposes. In addition, the Wilcox plot shows that $98 \%$ of the water samples belong to "good to permissible category" for irrigation use.
\end{abstract}




\section{Keywords}

Wilcox Diagram, Piper Plot, Geochemical Signature, Groundwater Evolution, Salinity Hazard, Irrigation, Groundwater

\section{Introduction}

Groundwater accounts for about 98 percent of the world's fresh water and is evenly distributed throughout the world. It provides a reasonably constant supply which is not completely susceptible to drying up under natural condition unlike surface water (Shitta, 2007; Fetter, 1993). All over the globe, groundwater has been a very good and important source of water supply for drinking, irrigation, municipal water supply, industrial purposes (Matthess, 1982). It is conveniently available at point of use and possesses excellent quality that requires little or no treatment in most cases. Therefore assessment of ground water for drinking, irrigation, and industrial has become a necessary and important task for present and future ground water quality management (Parker \& Foster, 1986; Lloyd \& Helmer, 1991) and policy makers, especially the Ondo State government, even as it calls for economy diversification to agriculture/irrigation farming, in order to reduce teeming unemployment rate among the youth in the State.

Ground water quality depends on the quality of recharged water, atmospheric precipitation, inland surface water and subsurface geochemical processes (Freeze \& Cherry, 1979; Todd, 1980; Fetter, 1983). Temporal changes in the origin and constitution of the recharged water, hydrologic and human factors may cause periodic changes in ground water quality (Fetter, 1990; Price, 1985). The geology of a particular area has a great influence on quality of water and its environment (Srinivasamoorthy et al., 2008; Raju, 2012; Vasanthavigar et al., 2010). The quality of ground water varies due to a change in chemical composition of the underlying sediments and aquifer (Subba Rao, 2017; Coulibaly \& Rodriguez, 2004; Backman et al., 1998). In Ondo State, modern civilization and urbanization, has consequently led to frequent discharging industrial effluent, domestic sewage and solid waste dump which could invariably cause ground water contamination (Thomson \& Foster, 1986). The polluted water not only affects water quality but also threatens human health, economic development and social prosperity. Hencecontinuous monitoring/assessment of water quality in relation to various standards around the world has become imperative in determination of suitability of water for various purposes (Satheesh et al., 2017).

Over the past decade there has been tremendous increased research on groundwater quality evaluation in the area of irrigation and hydrochemical facies characterization (Singh et al., 2015; Siddiqui et al., 2005; Srinivasamoorthy et al., 2008; Jain et al., 2010; Alam et al., 2012; Raju et al., 2009; Raju et al., 2011). Singh et al. (2015) evaluated the quality of groundwater and its suitability for 
domestic and irrigation uses in parts of the Chandauli-Varanasi region, Uttar Pradesn, India and concluded that Water Quality Index calculated exhibits poor quality in less percentage indicating the effective ion leaching, overexploitation and anthropogenic activities from discharge of effluents from agricultural and domestic uses in both seasons (pre and post monsoon). In addition, based on the classification of irrigation water according to sodium absorption ratio (SAR) and Permeability Index (PI) values, all the sample locations were suitable for irrigation purposes. Satheesh et al. (2017) also carried out groundwater quality assessment and hydrochemical facies evolution of Yeshwanthapur sub-basin, Marangal district, the study reveals that concentrations of the major ions and important physical parameters are within the permissible limits for irrigation SAR values ranged from $0.06 \mathrm{mg} / \mathrm{l}$ to $13.9 \mathrm{mg} / \mathrm{l}$ and the water falls in the class of "excellent to good category". Percent Sodium values indicate the most of groundwater samples belongs to very good to permissible category for irrigation on Wilcox diagram. Thus, the overall groundwater quality in the sub-basin was fresh and suitable for irrigation use. In this present study an assessment of the ground water quality in Akure metropolis is undertaken for irrigation. The objective is to study the hydrochemical facies, groundwater evolution, major geochemistry and evaluate water's suitability for irrigation purposes in line with the aspiration of the State Government to turn the state into industrial base (hub) and "food basket" of Nigeria.

\section{Description of the Study Area}

Akure falls within the basement complex region of Nigeria within Northings (790,796 - 809,322 mN and Eastings 733,683 - 752,092 mE, UTM Minna Zone 31) (Figure 1). It covers an aerial extent of about $320 \mathrm{~km}^{2}$. The metropolis is located on a gently undulating terrain surrounded by isolated hills and inselbergs (Ojo et al., 2014). Topographic elevations (Figure 2) vary between 260 and $470 \mathrm{~m}$ above sea level (Ojo et al., 2014). The major river in Akure is river Ala and its tributaries

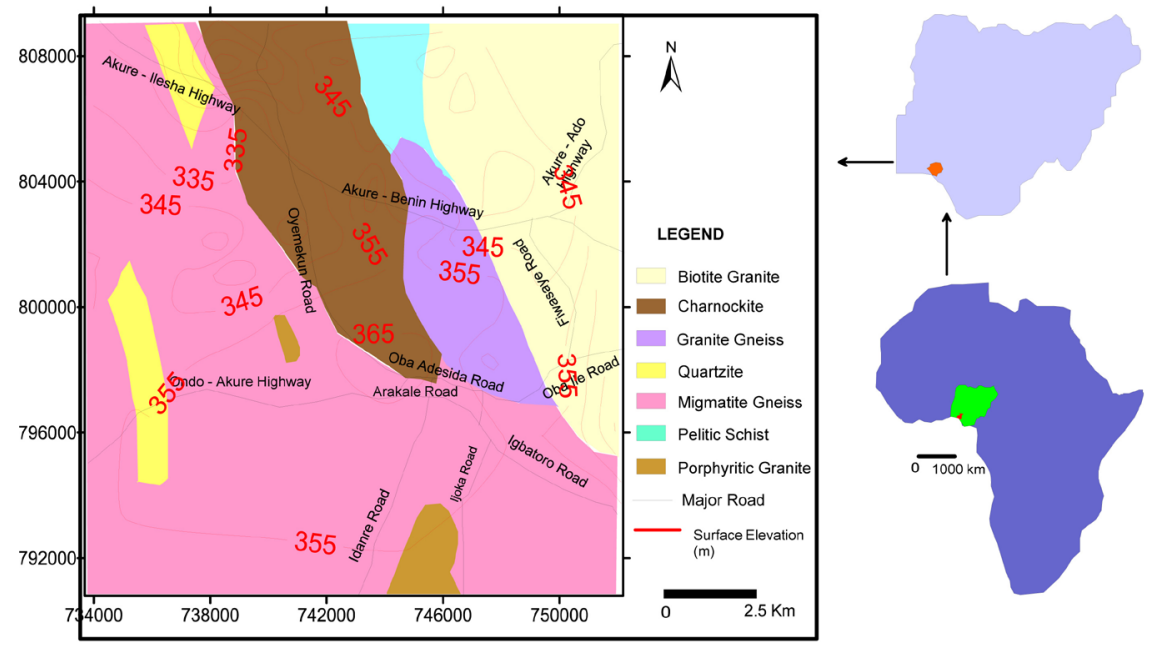

Figure 1. Location map of the study area on the map of Africa and Nigeria. 


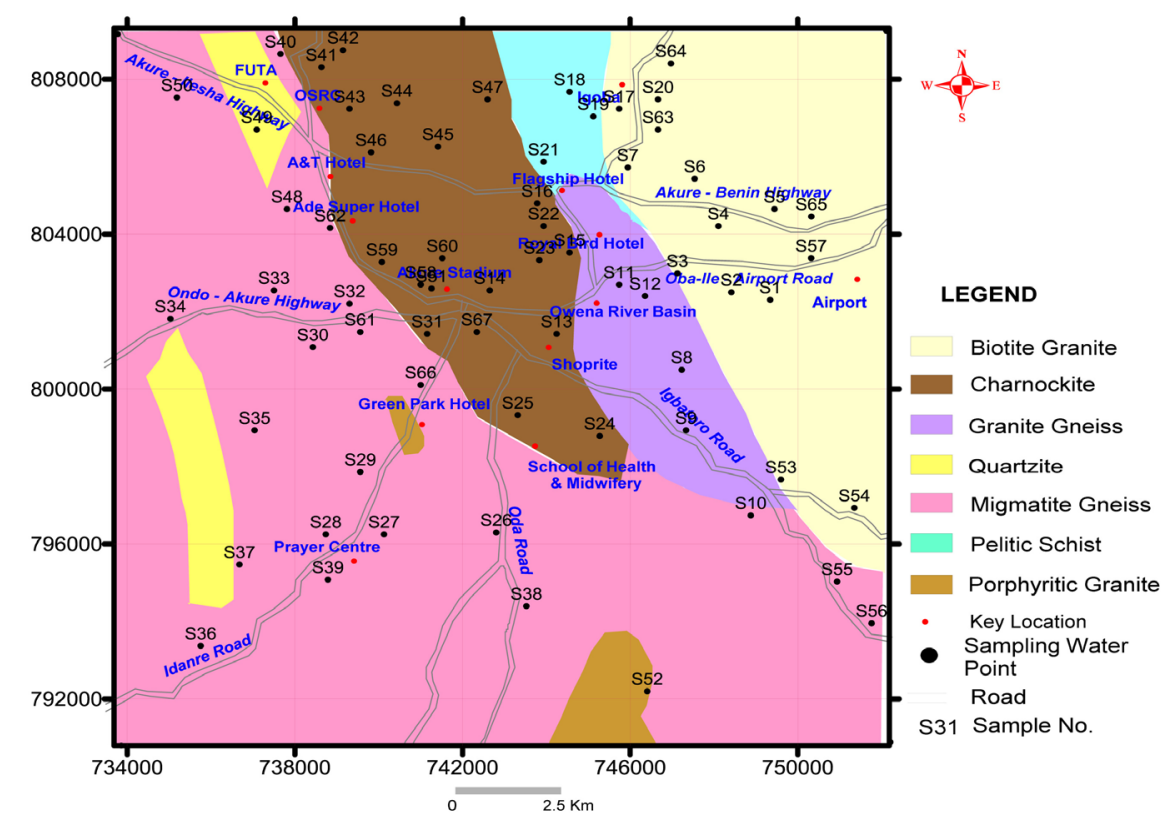

Figure 2. Base Map showing the Sample Nos. and Sampling Points on Geology.

such as Owuruwu river. Rivers such as Otenre river, Omi Atamo, are smaller rivers that serve as runoff in the town, which are tributaries of Ogbese river.

There are seven major different rock units in the area as shown in Figure 3, comprising of Migmatite-Gneiss, Quartzite, Charnokite, Biotite granite, Pelitic Schist, Granite Gneiss, and Granite. The Migmatite Gneiss occupies about 60\% of the area with an intrusion of Quartzite and Biotite Granite in some places like Alagbaka-Oda road, Akure-Idanre road. The granite rocks which are member of the older granite suit occupy about $65 \%$ of the total area of Akure. Three principal petrographic varieties are recognized, the fine-grained biotite granite, medium to coarse grained, non-porphyritic biotite-hornblende granite and coarse-porphyritic biotite hornblende granite. The classification is based largely on the textural characteristics. Also three main textural types of charnockitic rocks are also distinguished in Akure. These are the coarse-grained variety, massive fine grained and the gneissic fine-grained types. Unlike most of the older granite, the charnokite rocks do not occur in form of smooth rounded boulders and only a few low hills all forming oval to sub-circular and elongated bodies. All the charnockitic in the region are dark-greenish to greenish-grey rocks with bluish quartz are greenish feldspars. The study area exhibits varieties of structures such as foliation, schistosity, folds, faults, joints and fractures. The groundwater in a typical basement complex area like the Akure Metropolis, is contained in two major aquifer units, namely weathered and fractured basement aquifers (Aniya \& Shoeneick, 1992). The weathered layer aquifer is derived from chemical alteration processes while the fractured basement aquifer system is as a result of tectonic activities (Ojo et al., 2014). The weathered layer aquifer may occur singly or in combination with the fractured aquifer (Bayode et al., 2006). The direct exposure of the uppermost part of the vadose zone of the weathered layer 


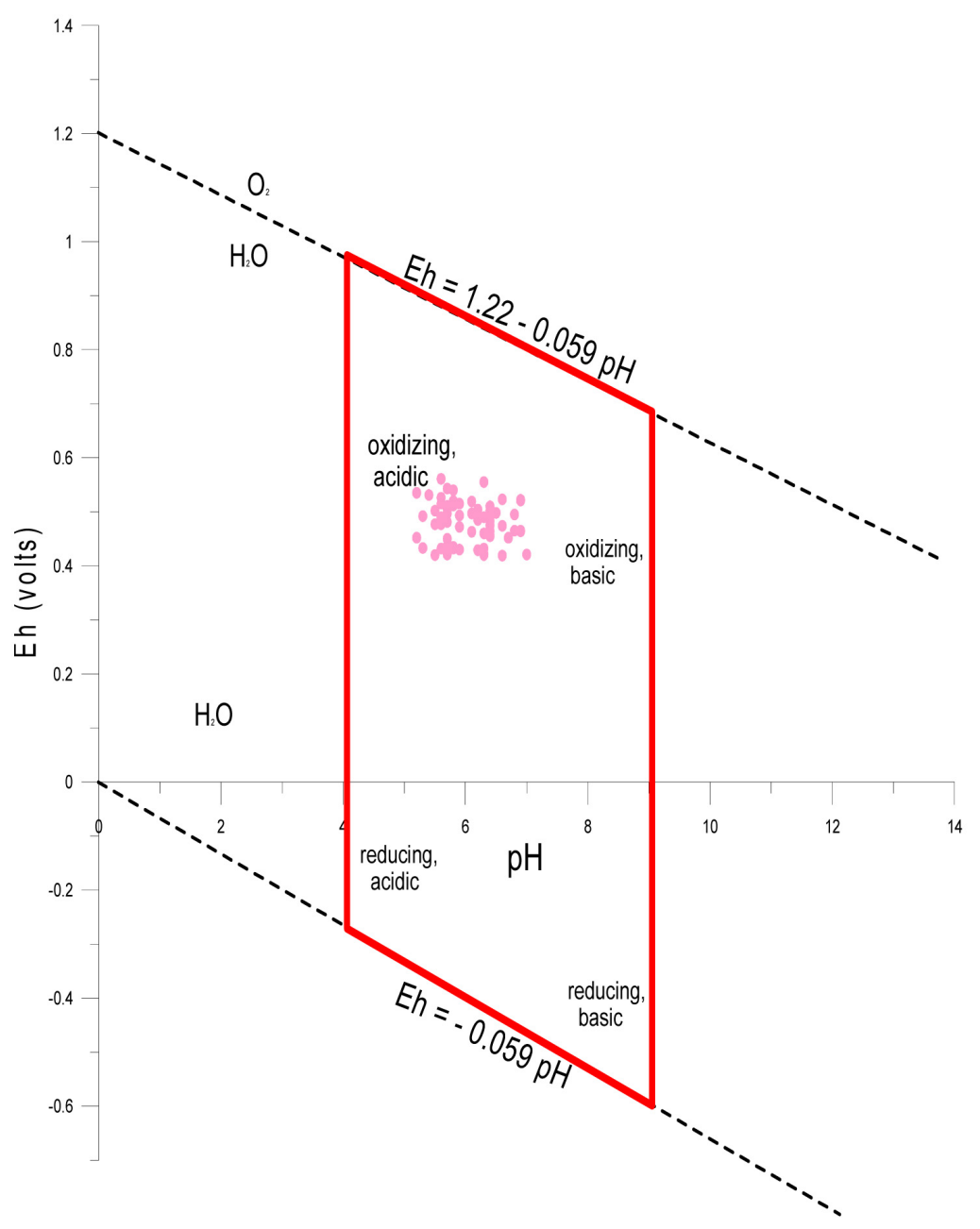

Figure 3. Framework of aqueous Eh-pH field showing a near oxidizing acidic condition for the sampled waters.

aquifer system makes it vulnerable to surface/near surface pollutants such as leachate from waste dump sites and flooding (Ojo et al., 2014).

\section{Methodology/Procedures}

Groundwater samples were collected at selected locations based on hydro-geomorphology and geology of the area (Driscoll, 1986; Hem, 1989) after hydrogeological investigations have been carried out to know the geochemical behavior (Scalf et al., 1981; Gibb et al., 1981). Consequently the map of the study area was first gridded into different zones (Figure 2) from which representative samples were collected and geo-referenced with the use of Global Positioning System (GARMIN 78 12-Channels). Sixty Seven (67) water samples were taken for a period of three (3) months. The samples were collected at depth levels (static water level) varying between $1.1-8.0 \mathrm{~m}$ and an average (avg.) of $3.7 \mathrm{~m}$. The hydraulic head of the sampled wells ranges between 320.2 and $392.1 \mathrm{~m}$ and an average (avg.) of $345.6 \mathrm{~m}$.

Physico-chemical parameters such as colour, turbidity, odour, taste, appear- 
ance, temperature, oxidation potential, $\mathrm{pH}$, total dissolved solid (TDS) and electrical conductivity (EC) were measured in the field by digital meters using the standard procedures (Scalf et al., 1981; Gibb et al., 1981). Sodium $\left(\mathrm{Na}^{+}\right)$and potassium $\left(\mathrm{K}^{+}\right)$were determined by using flame photometer. Calcium $\left(\mathrm{Ca}^{2+}\right)$, magnesium $\left(\mathrm{Mg}^{2+}\right)$, bicarbonate $\left(\mathrm{HCO}_{3}^{-}\right)$, hardness, alkalinity and chloride $\left(\mathrm{Cl}^{-}\right)$ were analyzed by titrimetric method. Sulfate $\left(\mathrm{SO}_{4}^{2-}\right)$, and nitrate $\left(\mathrm{NO}_{3}^{-}\right)$employed spectrophotometer model. The chemical data of groundwater samples are subjected to compute the ionic-balance-error between the total concentration of cations $\left(\mathrm{Ca}^{2+}, \mathrm{Mg}^{2+}, \mathrm{Na}^{+}\right.$and $\left.\mathrm{K}^{+}\right)$and total concentration of anions $\left(\mathrm{HCO}_{3}^{-}, \mathrm{Cl}^{-}, \mathrm{SO}_{4}^{2-}\right.$, and $\left.\mathrm{NO}_{3}^{-}\right)$for testing accuracy of chemical analysis of each groundwater samples, before the interpretation of the chemical data is undertaken. The value of the ionic-balance-error is observed to be within the acceptable limit of $\pm 10 \%$ (Domenico \& Schwartz, 1990) using Equation (1).

$$
\mathrm{IBE}=\frac{(\mathrm{TCC}+\mathrm{TCA})}{\mathrm{TCC}-\mathrm{TCA}} \times 100
$$

where,

$$
\text { TCC }=\text { total concentration of cations }
$$

$\mathrm{TCA}=$ total concentration of anions

\section{Results and Discussion}

\subsection{Physical and Chemical Parameters}

The chemical composition of groundwater can be used to delineate the recharge and discharge areas on the basis of hydrogeochemical facies and genetic classification (Subba Rao, 2017; Domenico \& Schwartz, 1990). The results of the physico-chemical parameters are presented in Table 1 to Table 2. The temperature of the groundwater varies from $25.9^{\circ} \mathrm{C}-30.8^{\circ} \mathrm{C}$ with a mean of $27.9^{\circ} \mathrm{C}$. This range of values shows a uniformly moderate temperature. All the water samples are colourless, odourless, and tasteless, with clear appearance. The turbidity of water ranges from 0.6 to $9.5 \mathrm{NTU}$ and an average of $3.16 \mathrm{NTU}$. This indicates that they are characterized with less suspended matter such as clay, silt, fine fragments of organic matter, and similar material. The $\mathrm{pH}$ plays a vital role to react with acidic or alkaline. It is controlled by $\mathrm{CO}_{2}-\mathrm{CO}_{3}^{2-}-\mathrm{HCO}_{3}^{-}$equilibrium (Subba Rao et al., 2002). The combination of $\mathrm{CO}_{2}$ with $\mathrm{H}_{2} \mathrm{O}$ (water) forms $\mathrm{H}_{2} \mathrm{CO}_{3}$ (carbonic acid), which affects the $\mathrm{pH}$ of water. Water can be classified as acidic and alkaline on the basis of $\mathrm{pH}$, which varies from 1 to 14 . The recorded $\mathrm{pH}$ varies from $5.2-7.8$ in the groundwater. As per the classification of $\mathrm{pH}$, the water is characterized by an acidic condition, as $\mathrm{H}^{+}$is more than $\mathrm{OH}^{-}$in the water (Subba Rao, 2017).

The oxidation potential (Eh) shows a positive value $(0.4190-0.5610$ volts $)$ which indicates that the water is an oxidizing type (Fetter, 1990). From Figure 3, it shows a near oxidizing acidic water. Total alkalinity (TA) is a measure of the capacity of water to neutralize acid in terms of calcium carbonate $\left(\mathrm{CaCO}_{3}\right)$. The TA is in between $40-340 \mathrm{mg} / \mathrm{l}$ (avg. $123.9 \mathrm{mg} / \mathrm{l}$ ). The concentration of total 
Table 1. Result obtained from the physical parameters measured/examined.

\begin{tabular}{|c|c|c|c|c|c|c|}
\hline Well No. & Temp $\left({ }^{\circ} \mathrm{C}\right)$ & $\mathrm{pH}$ & TDS & $\mathrm{EC}(\mu \mathrm{S} / \mathrm{cm})$ & Eh (volts) & Turb. NTU \\
\hline 1 & 30.8 & 6.4 & 100 & 204 & 0.483 & 1.8 \\
\hline 2 & 28.4 & 5.6 & 73 & 145 & 0.432 & 1.5 \\
\hline 3 & 30.4 & 5.5 & 75 & 151 & 0.420 & 2.5 \\
\hline 4 & 27.6 & 5.6 & 65 & 131 & 0.477 & 2.9 \\
\hline 5 & 28.1 & 6.4 & 376 & 754 & 0.464 & 8.6 \\
\hline 6 & 29.3 & 5.8 & 56 & 115 & 0.512 & 1.2 \\
\hline 7 & 29.4 & 5.7 & 50 & 101 & 0.511 & 1.5 \\
\hline 8 & 28.5 & 5.7 & 42 & 83 & 0.543 & 2.2 \\
\hline 9 & 29.6 & 5.6 & 50 & 101 & 0.561 & 3.4 \\
\hline 10 & 29.2 & 6.2 & 91 & 181 & 0.485 & 1.1 \\
\hline 11 & 29.2 & 5.7 & 150 & 303 & 0.481 & 1.2 \\
\hline 12 & 30.5 & 5.6 & 74 & 152 & 0.515 & 4.6 \\
\hline 13 & 29.6 & 5.7 & 66 & 132 & 0.505 & 6.2 \\
\hline 14 & 30.1 & 6.4 & 130 & 61 & 0.457 & 5.1 \\
\hline 15 & 29.6 & 5.7 & 64 & 127 & 0.450 & 6.5 \\
\hline 16 & 29.8 & 6.4 & 50 & 101 & 0.475 & 8.2 \\
\hline 17 & 27.4 & 6.3 & 78 & 156 & 0.460 & 4.2 \\
\hline 18 & 28.2 & 7.0 & 424 & 874 & 0.421 & 1.2 \\
\hline 19 & 27.0 & 6.6 & 281 & 563 & 0.419 & 1.5 \\
\hline 20 & 28.2 & 6.3 & 143 & 286 & 0.432 & 2.3 \\
\hline 21 & 27.4 & 6.6 & 165 & 331 & 0.474 & 1.8 \\
\hline 22 & 29.5 & 5.3 & 40 & 79 & 0.492 & 1.5 \\
\hline 23 & 27.5 & 5.8 & 161 & 323 & 0.435 & 1.1 \\
\hline 24 & 28.2 & 5.6 & 65 & 131 & 0.480 & 0.8 \\
\hline 25 & 26.8 & 5.5 & 62 & 124 & 0.477 & 4.7 \\
\hline 26 & 27.5 & 5.6 & 42 & 84 & 0.481 & 1.2 \\
\hline 27 & 26.4 & 5.2 & 101 & 203 & 0.535 & 3.5 \\
\hline 28 & 28.5 & 5.5 & 83 & 167 & 0.502 & 2.5 \\
\hline 29 & 27.8 & 5.6 & 73 & 146 & 0.490 & 1.2 \\
\hline 30 & 28.4 & 6.3 & 112 & 224 & 0.555 & 4.4 \\
\hline 31 & 25.7 & 5.9 & 57 & 114 & 0.493 & 3.2 \\
\hline 32 & 27.5 & 5.6 & 105 & 210 & 0.526 & 5.8 \\
\hline 33 & 27.6 & 6.8 & 119 & 238 & 0.495 & 6.9 \\
\hline 34 & 28.1 & 6.3 & 123 & 246 & 0.490 & 7.8 \\
\hline 35 & 26.8 & 6.4 & 84 & 169 & 0.501 & 0.6 \\
\hline 36 & 26.5 & 6.5 & 89 & 179 & 0.498 & 1.2 \\
\hline 37 & 27.7 & 6.9 & 101 & 202 & 0.521 & 1.5 \\
\hline 38 & 28.3 & 5.9 & 63 & 127 & 0.430 & 1.8 \\
\hline 39 & 27.9 & 5.8 & 48 & 96 & 0.540 & 1.2 \\
\hline
\end{tabular}


O. O. Falowo et al.

\section{Continued}

\begin{tabular}{|c|c|c|c|c|c|c|}
\hline 40 & 29.8 & 6.4 & 44 & 89 & 0.455 & 1.2 \\
\hline 41 & 27.2 & 6.2 & 57 & 114 & 0.504 & 1.3 \\
\hline 42 & 27.6 & 6.4 & 103 & 206 & 0.490 & 1.2 \\
\hline 43 & 27.5 & 6.9 & 50 & 101 & 0.464 & 1.4 \\
\hline 44 & 27.3 & 6.4 & 72 & 144 & 0.510 & 1.6 \\
\hline 45 & 27.1 & 6.1 & 78 & 157 & 0.519 & 1.4 \\
\hline 46 & 26.5 & 6.1 & 57 & 115 & 0.497 & 2.2 \\
\hline 47 & 27.8 & 6.9 & 49 & 98 & 0.465 & 3.2 \\
\hline 48 & 27.5 & 6.3 & 46 & 91 & 0.420 & 4.5 \\
\hline 49 & 27.4 & 6.2 & 83 & 166 & 0.429 & 6.8 \\
\hline 50 & 27.2 & 6.8 & 331 & 662 & 0.465 & 4.8 \\
\hline 51 & 27.8 & 6.7 & 125 & 250 & 0.452 & 1.5 \\
\hline 52 & 27.5 & 5.8 & 142 & 285 & 0.432 & 1.1 \\
\hline 53 & 27.6 & 6.1 & 53 & 108 & 0.463 & 1.4 \\
\hline 54 & 27.7 & 5.7 & 62 & 125 & 0.421 & 4.4 \\
\hline 55 & 28.3 & 5.9 & 41 & 83 & 0.472 & 5.8 \\
\hline 56 & 27.4 & 6.3 & 54 & 108 & 0.422 & 7.9 \\
\hline 57 & 27.9 & 6.6 & 115 & 231 & 0.523 & 4.5 \\
\hline 58 & 27.3 & 6.9 & 174 & 348 & 0.522 & 2.6 \\
\hline 59 & 26.1 & 6.2 & 52 & 228 & 0.490 & 1.2 \\
\hline 60 & 26.5 & 5.9 & 89 & 178 & 0.515 & 1.2 \\
\hline 61 & 26.9 & 6.5 & 46 & 53 & 0.498 & 1.2 \\
\hline 62 & 27.8 & 5.8 & 62 & 122 & 0.520 & 5.5 \\
\hline 63 & 28.4 & 5.4 & 78 & 156 & 0.531 & 9.5 \\
\hline 64 & 26.3 & 5.7 & 42 & 98 & 0.437 & 6.5 \\
\hline 65 & 26.9 & 5.3 & 47 & 101 & 0.433 & 4.2 \\
\hline 66 & 26.1 & 5.2 & 150 & 122 & 0.452 & 2.2 \\
\hline 67 & 26.4 & 5.7 & 48 & 65 & 0.497 & 1.2 \\
\hline Min. & 25.9 & 5.2 & 40 & 53 & 0.419 & 0.6 \\
\hline Max. & 30.8 & 7.0 & 424 & 874 & 0.561 & 9.5 \\
\hline Average & 27.9 & 6.0 & 96.7 & 189.8 & 0.481 & 3.16 \\
\hline
\end{tabular}

Table 2. Summary of the analyzed chemical parameters.

\begin{tabular}{cccccccccccc}
\hline Well No. & T.A & Acidity & T.H & $\mathrm{HCO}_{3}^{-}$ & $\mathrm{Ca}^{2+}$ & $\mathrm{Mg}^{2+}$ & $\mathrm{Cl}^{-}$ & $\mathrm{Na}^{+}$ & $\mathrm{K}^{+}$ & $\mathrm{SO}_{4}^{2-}$ & $\mathrm{NO}_{3}^{-}$ \\
\hline 1 & 180 & 360 & 228 & 219.5 & 52.5 & 5.72 & 49.7 & 5.4 & 10.5 & 3.2 & 1.1 \\
2 & 210 & 220 & 10 & 120.1 & 23.3 & 0.9 & 5.5 & 2.5 & 2.3 & 0.9 & 0.9 \\
3 & 150 & 200 & 20 & 142.2 & 14.5 & 0.8 & 15.5 & 2.8 & 4.5 & 1.2 & 0.8 \\
4 & 40 & 260 & 55 & 123.4 & 21.2 & 2.2 & 20.5 & 2.9 & 9.5 & 2.5 & 4.5 \\
5 & 340 & 380 & 392 & 214.8 & 60.9 & 19.5 & 74.5 & 4.2 & 7.8 & 4.5 & 1.3 \\
6 & 60 & 280 & 88 & 73.2 & 10.0 & 3.8 & 17.7 & 3.0 & 5.7 & 6.0 & 4.5 \\
\hline
\end{tabular}




\section{Continued}

\begin{tabular}{|c|c|c|c|c|c|c|c|c|c|c|c|}
\hline 7 & 85 & 210 & 65 & 54.5 & 11.2 & 2.8 & 20.5 & 2.8 & 10.2 & 5.5 & 3.2 \\
\hline 8 & 60 & 260 & 84 & 73.2 & 13.4 & 2.9 & 14.2 & 2.4 & 8.8 & 12.5 & 0.9 \\
\hline 9 & 60 & 460 & 68 & 73.2 & 10.9 & 2.5 & 12.4 & 2.1 & 9.8 & 7.5 & 1.1 \\
\hline 10 & 90 & 320 & 68 & 63.4 & 22.1 & 8.2 & 24.3 & 2.2 & 4.6 & 2.4 & 3.5 \\
\hline 11 & 120 & 250 & 112 & 51.2 & 22.3 & 4.4 & 18.9 & 3.4 & 6.8 & 0.9 & 8.2 \\
\hline 12 & 140 & 180 & 84 & 170.8 & 15.1 & 2.7 & 23.8 & 4.3 & 7.0 & 13.5 & 3.4 \\
\hline 13 & 180 & 290 & 45 & 111.2 & 11.4 & 3.3 & 25.5 & 10.1 & 9.2 & 3.3 & 3.2 \\
\hline 14 & 140 & 260 & 52 & 170.8 & 20.9 & 0.9 & 33.7 & 2.4 & 4.5 & 5.5 & 5.9 \\
\hline 15 & 140 & 240 & 42 & 85.3 & 9.5 & 1.1 & 14.2 & 9.8 & 4.6 & 1.2 & 8.2 \\
\hline 16 & 100 & 200 & 88 & 122.1 & 16.8 & 2.9 & 14.2 & 2.0 & 4.4 & 8.5 & 7.4 \\
\hline 17 & 140 & 200 & 152 & 170.8 & 25.2 & 5.2 & 17.5 & 2.8 & 7.3 & 12.2 & 0.9 \\
\hline 18 & 60 & 380 & 96 & 73.2 & 25.3 & 1.9 & 28.4 & 2.6 & 11.8 & 4.7 & 0.8 \\
\hline 19 & 40 & 320 & 83 & 40.3 & 20.2 & 1.2 & 30.2 & 6.5 & 15.2 & 4.1 & 0.9 \\
\hline 20 & 70 & 300 & 62 & 20.3 & 11.2 & 1.3 & 33.2 & 8.8 & 12.2 & 2.3 & 1.1 \\
\hline 21 & 260 & 340 & 264 & 317.2 & 57.9 & 7.9 & 10.6 & 5.2 & 7.9 & 2.5 & 1.2 \\
\hline 22 & 100 & 400 & 60 & 122.1 & 11.7 & 1.9 & 12.4 & 10.2 & 6.1 & 13.7 & 1.9 \\
\hline 23 & 190 & 380 & 48 & 68.3 & 14.5 & 1.4 & 42.2 & 2.9 & 4.4 & 3.3 & 2.2 \\
\hline 24 & 60 & 220 & 84 & 73.2 & 31.6 & 0.8 & 14.2 & 11.5 & 6.0 & 4.5 & 1.5 \\
\hline 25 & 80 & 410 & 92 & 44.9 & 16.5 & 1.1 & 32.1 & 14.2 & 6.2 & 9.9 & 3.1 \\
\hline 26 & 40 & 400 & 38 & 48.8 & 15.4 & 0.9 & 12.3 & 3.8 & 8.7 & 9.5 & 0.8 \\
\hline 27 & 200 & 360 & 116 & 244.0 & 25.3 & 3.1 & 23.8 & 4.6 & 4.2 & 11.5 & 3.4 \\
\hline 28 & 70 & 260 & 55 & 33.5 & 23.3 & 5.6 & 12.2 & 5.0 & 5.8 & 8.4 & 2.3 \\
\hline 29 & 300 & 500 & 292 & 366 & 54.1 & 16.5 & 44.3 & 4.9 & 6.9 & 12.2 & 4.5 \\
\hline 30 & 100 & 290 & 165 & 15.2 & 22.3 & 2.2 & 5.5 & 6.9 & 12.3 & 6.2 & 1.2 \\
\hline 31 & 60 & 340 & 108 & 73.2 & 18.5 & 3.6 & 12.3 & 2.7 & 10.1 & 15.7 & 0.9 \\
\hline 32 & 80 & 340 & 152 & 97.6 & 21.7 & 5.7 & 23.8 & 3.7 & 8.8 & 6.5 & 1.2 \\
\hline 33 & 82 & 310 & 182 & 18.3 & 20.4 & 4.4 & 2.5 & 8.8 & 5.5 & 2.2 & 1.4 \\
\hline 34 & 110 & 300 & 122 & 20.2 & 18.2 & 2.2 & 3.9 & 19.5 & 3.2 & 2.4 & 3.8 \\
\hline 35 & 150 & 310 & 145 & 22.5 & 18.4 & 1.3 & 8.8 & 12.2 & 4.2 & 3.5 & 5.6 \\
\hline 36 & 320 & 420 & 140 & 390.4 & 23.5 & 4.7 & 10.5 & 2.3 & 9.3 & 8.1 & 6.2 \\
\hline 37 & 100 & 320 & 25 & 42.2 & 22.4 & 9.4 & 18.2 & 4.1 & 10.2 & 5.5 & 0.9 \\
\hline 38 & 140 & 300 & 28 & 33.2 & 10.2 & 4.1 & 20.1 & 3.9 & 11.1 & 1.8 & 0.8 \\
\hline 39 & 80 & 450 & 35 & 45.0 & 8.8 & 6.0 & 14.3 & 3.8 & 10.5 & 1.1 & 0.8 \\
\hline 40 & 60 & 400 & 44 & 90.1 & 14.5 & 1.5 & 21.1 & 10.1 & 6.2 & 4.2 & 0.9 \\
\hline 41 & 60 & 420 & 72 & 73.2 & 14.1 & 2.0 & 10.6 & 3.0 & 10.6 & 9.5 & 1.6 \\
\hline 42 & 40 & 340 & 63 & 122.1 & 30.1 & 1.8 & 15.2 & 9.4 & 5.2 & 6.5 & 4.5 \\
\hline 43 & 160 & 300 & 132 & 195.2 & 25.3 & 4.4 & 12.3 & 10.7 & 10.2 & 3.7 & 4.4 \\
\hline 44 & 80 & 400 & 71 & 82.2 & 33.2 & 6.2 & 13.4 & 8.5 & 8.1 & 7.3 & 3.3 \\
\hline
\end{tabular}




\begin{tabular}{|c|c|c|c|c|c|c|c|c|c|c|c|}
\hline \multicolumn{12}{|c|}{ Continued } \\
\hline 45 & 100 & 420 & 136 & 122.0 & 25.3 & 4.2 & 23.8 & 2.5 & 11.5 & 4.5 & 3.4 \\
\hline 46 & 200 & 440 & 92 & 244.0 & 18.5 & 2.6 & 7.1 & 2.1 & 10.9 & 5.5 & 4.8 \\
\hline 47 & 160 & 380 & 80 & 195.2 & 15.4 & 2.7 & 10.5 & 11.9 & 8.3 & 3.2 & 8.7 \\
\hline 48 & 120 & 400 & 45 & 56.6 & 14.2 & 7.2 & 8.8 & 2.9 & 4.4 & 1.3 & 8.4 \\
\hline 49 & 100 & 410 & 62 & 54.4 & 20.1 & 8.6 & 8.2 & 2.6 & 3.3 & 1.5 & 4.4 \\
\hline 50 & 60 & 350 & 60 & 38.2 & 19.9 & 9.9 & 12.5 & 3.4 & 2.2 & 2.6 & 6.5 \\
\hline 51 & 200 & 200 & 164 & 244.0 & 18.5 & 6.7 & 23.8 & 3.2 & 7.8 & 4.1 & 1.5 \\
\hline 52 & 40 & 300 & 113 & 24.5 & 17.7 & 1.5 & 19.0 & 3.5 & 10.1 & 2.8 & 1.6 \\
\hline 53 & 120 & 380 & 72 & 146.4 & $15 . .2$ & 2.0 & 10.5 & 2.8 & 4.9 & 8.5 & 3.2 \\
\hline 54 & 80 & 220 & 63 & 56.8 & 18.5 & 6.2 & 19.0 & 4.4 & 6.3 & 8.9 & 1.9 \\
\hline 55 & 100 & 380 & 76 & 122.1 & 20.9 & 1.9 & 12.2 & 6.5 & 10.0 & 3.0 & 0.9 \\
\hline 56 & 110 & 240 & 44 & 44.2 & 9.8 & 3.3 & 18.1 & 3.4 & 3.3 & 4.5 & 3.4 \\
\hline 57 & 200 & 580 & 292 & 244.0 & 37.1 & 11.8 & 15.9 & 3.1 & 10.5 & 3.5 & 1.3 \\
\hline 58 & 200 & 380 & 244 & 244.2 & 47.1 & 7.9 & 8.8 & 3.1 & 7.7 & 4.2 & 1.2 \\
\hline 59 & 210 & 250 & 182 & 25.8 & 10.5 & 4.1 & 15.2 & 9.5 & 2.9 & 9.8 & 1.8 \\
\hline 60 & 250 & 310 & 120 & 55.5 & 12.2 & 1.0 & 12.2 & 2.9 & 4.2 & 3.6 & 4.4 \\
\hline 61 & 120 & 240 & 52 & 146.4 & 18.4 & 0.8 & 13.2 & 3.2 & 5.9 & 1.4 & 4.2 \\
\hline 62 & 120 & 300 & 42 & 92.2 & 16.4 & 3.2 & 39.4 & 2.6 & 4.1 & 2.5 & 1.7 \\
\hline 63 & 120 & 420 & 135 & 145.2 & 23.5 & 4.5 & 14.3 & 2.8 & 10.5 & 1.1 & 5.7 \\
\hline 64 & 100 & 300 & 72 & 122.1 & 22.7 & 1.5 & 20.2 & 3.9 & 4.8 & 1.4 & 5.9 \\
\hline 65 & 100 & 300 & 64 & 122.1 & 21.8 & 1.5 & 22.3 & 2.9 & 23.6 & 2.5 & 6.5 \\
\hline 66 & 40 & 200 & 52 & 55.8 & 10.0 & 3.2 & 20.1 & 4.4 & 10.6 & 3.5 & 7.8 \\
\hline 67 & 80 & 180 & 68 & 97.6 & 20.1 & 1.2 & 39.5 & 1.4 & 6.3 & 1.7 & 8.2 \\
\hline Min & 40 & 180 & 10 & 15.2 & 8.8 & 0.8 & 2.5 & 1.4 & 2.2 & 0.9 & 0.8 \\
\hline Max & 340 & 580 & 392 & 390.4 & 60.9 & 19.5 & 74.5 & 19.5 & 23.6 & 15.7 & 8.7 \\
\hline Mean & 123 & 323 & 101 & 112.1 & 21.3 & 4.0 & 19.2 & 5.1 & 7.7 & 5.2 & 3.2 \\
\hline
\end{tabular}

hardness (TH) varies between 10 and $392 \mathrm{mg} / \mathrm{l}$, and acidity ranging from 180 $\mathrm{mg} / \mathrm{l}$ to $580 \mathrm{mg} / \mathrm{l}$. The concentration of $\mathrm{Ca}^{2+}$ varies from $8.8-60.9 \mathrm{mg} / \mathrm{l}$ with average of $21.3 \mathrm{mg} / \mathrm{l}$. The $\mathrm{Mg}^{2+}$ ranges from $0.8-19.5 \mathrm{mg} / \mathrm{l}$ (avg. $4.0 \mathrm{mg} / \mathrm{l}$ ). Sodium $\left(\mathrm{Na}^{+}\right)$ranges from $1.4-19.5 \mathrm{mg} / \mathrm{l}$ with an average value of $5.1 \mathrm{mg} / \mathrm{l}$. The concentrations of $\mathrm{Na}^{+}$in the samples is generally low and could be attributed to less influence of anthropogenic activities on the groundwater and it ranges from 1.4 $19.5 \mathrm{mg} / \mathrm{l}$. The potassium $\left(\mathrm{K}^{+}\right.$) is in between $2.2 \mathrm{mg} / \mathrm{l}$ and $23.6 \mathrm{mg} / \mathrm{l}$ (avg. 7.7 $\mathrm{mg} / \mathrm{l}$ ), important sources include orthoclase feldspar, nepheline, leucite and biotite (Subba Rao, 2017; Back, 1960; Collins \& Jenkins, 1996).

The bicarbonate $\left(\mathrm{HCO}_{3}^{-}\right.$) varies from 15.2 - $390.4 \mathrm{mg} / \mathrm{l}$ (avg. $\left.112.1 \mathrm{mg} / \mathrm{l}\right)$. Soil $\mathrm{CO}_{2}$ is the likely main source of $\mathrm{HCO}_{3}^{-}$in the groundwater (Fetter, 1983). In addition decay of organic matter could also releases carbon dioxide for dissolution. The analyzed water samples contain sulfate $\left(\mathrm{SO}_{4}^{2-}\right)$ in the range of 0.91 $15.7 \mathrm{mg} / \mathrm{l}$ (avg. $5.2 \mathrm{mg} / \mathrm{l})$. The Chloride $\left(\mathrm{Cl}^{-}\right)$is dissolved from rocks and soils in 
the study area, and its values range from $2.5-74.5 \mathrm{mg} / \mathrm{l}$.

Excessive concentrations of dissolved ions in the irrigation water affect plants and agricultural soil physically and chemically through lowering of osmotic pressure in the plant structural cells. This prevents water from reaching the branches and leaves, thus reducing the agricultural productivity (Fetter, 1993). Salinity hazard, sodium, percent sodium $\left(\% \mathrm{Na}^{+}\right)$, permeability index (PI), residual sodium carbonate (RSC), magnesium ratio (MR) and Kelly ratio (KR) are widely used for the assessment of water quality for irrigation. Figure 4 shows the trilinear diagram of the water samples, which is an effective tool for segregating data for critical study with respect to the sources of dissolved ions in water and modifications in water character (Piper, 1944). Generally the water in the study area fall within zone 5 which comes under carbonate hardness or fresh water type (Table 3). They are characterized by $\mathrm{Ca}^{2+}$ and $\mathrm{Mg}^{2+}$ of $\mathrm{HCO}_{3}^{-}$and $\mathrm{CO}_{3}^{2-}$ over $\mathrm{Na}^{+}$and $\mathrm{K}^{+}$of $\mathrm{Cl}^{-}$and $\mathrm{SO}_{4}^{2-}$. Only few samples (about 5\%) belongs to mixed type (transition zone) where no cation-anion pair exceeds $50 \%$. The mechanism controlling the groundwater quality for the water samples determined using Gibb's diagrams, by relating the ratio of the cations $\left(\mathrm{Na}^{+}+\mathrm{K}^{+}: \mathrm{Na}^{+}+\mathrm{K}^{+}+\right.$ $\left.\mathrm{Ca}^{2+}\right)$ and ratio of anions $\left(\mathrm{Cl}^{-}: \mathrm{Cl}^{-}+\mathrm{HCO}_{3}^{-}\right)$which are plotted against TDS, for understanding the mechanisms that control the groundwater chemistry with respect to atmospheric precipitation (rainfall), rock-water interaction and evaporation. From Figure 5, the chemistry of the water falls in the precipitation domain, indicating a meteoric origin. Hence the soil/rock-water interaction is responsible for the source of dissolved ions.

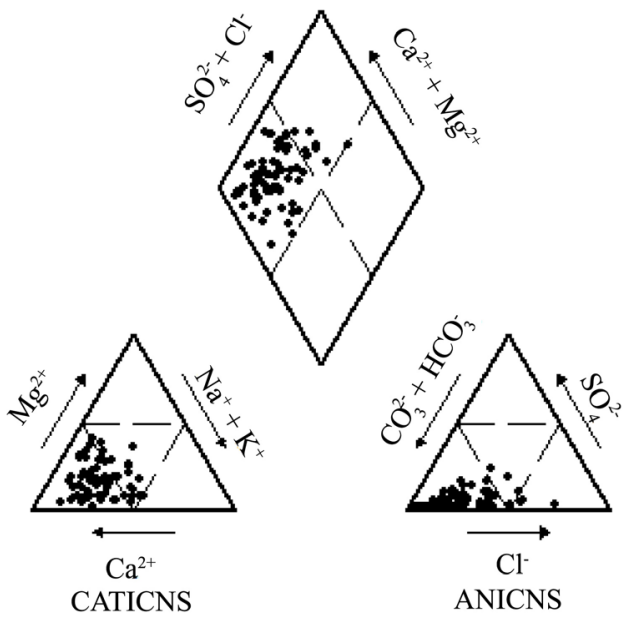

(a)
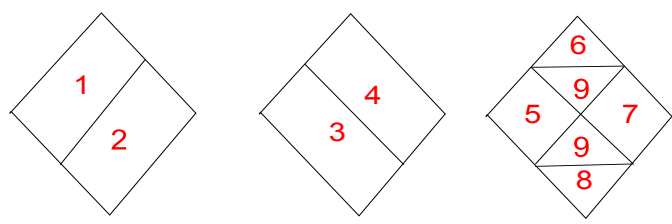

(b)

Figure 4. (a) Piper's trilinear diagram for water samples (b) showing a predominant zone 5 water type. 


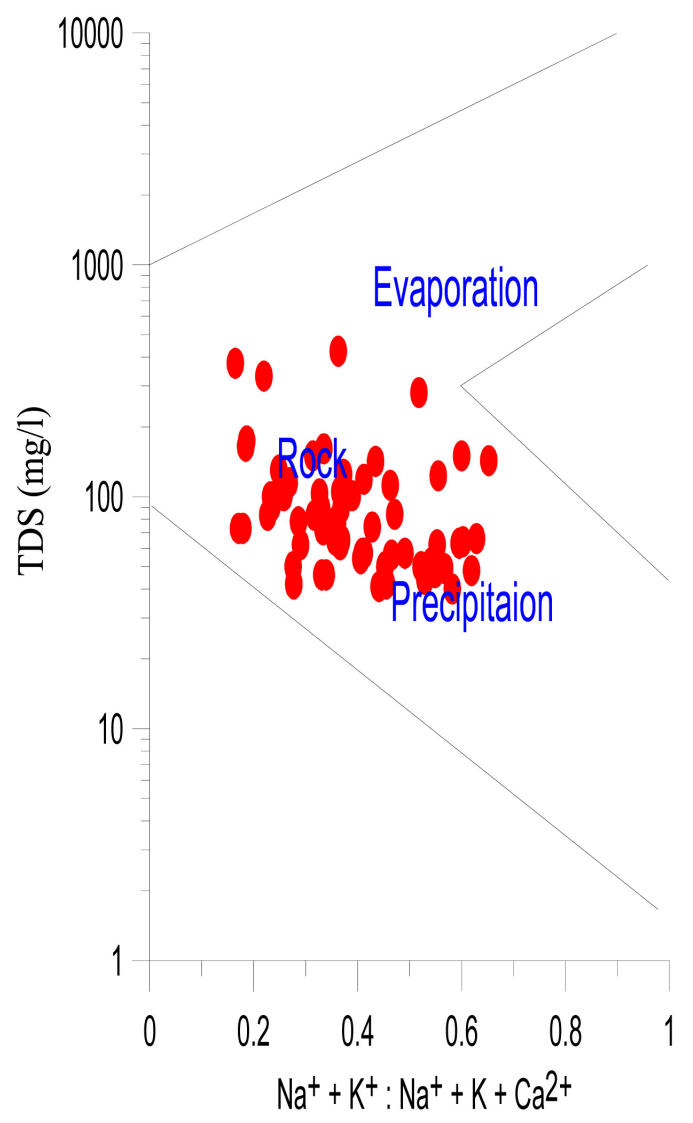

(a)

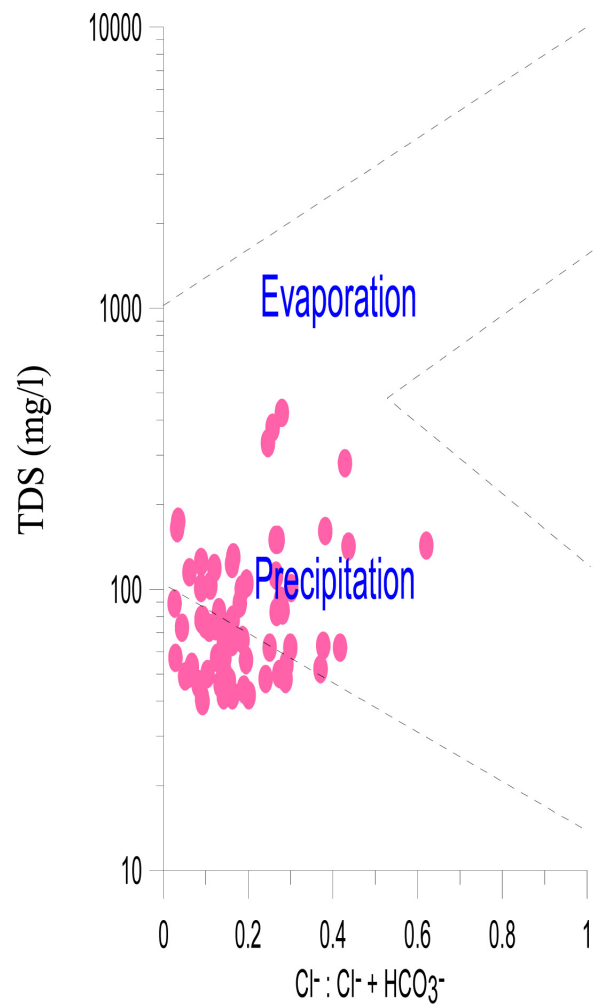

(b)

Figure 5. Mechanisms controlling groundwater chemistry in the study area. 
Table 3. Characterization of water quality using interpreted trilinear diagram.

\begin{tabular}{|c|c|}
\hline Zone & Characterization of water quality \\
\hline 1 & Alkaline earths $\left(\mathrm{Ca}^{2+}+\mathrm{Mg}^{2+}\right)$ exceed alkalies $\left(\mathrm{Na}^{+}+\mathrm{K}^{+}\right)$ \\
\hline 2 & Alkalies exceed alkaline earths \\
\hline 3 & Weak acids $\mathrm{HCO}_{3}^{-}+\mathrm{CO}_{3}^{2-}$ exceed strong acid $\mathrm{Cl}^{-}+\mathrm{SO}_{4}^{2-}$ \\
\hline 4 & Strong acids exceed weak acids \\
\hline 5 & $\begin{array}{c}\text { Carbonate hardness (secondary alkalinity) exceeds } 50 \% \\
\text { that is by alkaline earths and weak acids }\end{array}$ \\
\hline 6 & Non-carbonate hardness (secondary salinity) exceeds $50 \%$ \\
\hline 7 & Non-carbonate alkali (primary salinity) exceeds $50 \%$ \\
\hline 8 & Carbonate alkali (primary alkalinity) exceeds $50 \%$ \\
\hline 9 & Mixed type (transition zone)-No cation-anion pair exceeds $50 \%$ \\
\hline
\end{tabular}

Consequently since the value of TDS is less than $1000 \mathrm{mg} / \mathrm{l}$ in the samples, the origin of the ions in the water samples is presumed to be the rock units in the area (geogenic origin).

\subsection{The Groundwater Evolution}

The evolution of groundwater quality is represented in Langelier and Ludwig's graphical diagram, as shown in Figure 6. The groundwater samples fall in Group I, relating to $\mathrm{Ca}^{2+}+\mathrm{Mg}^{2+}+\mathrm{HCO}_{3}^{-}$Type, which indicates a meteoric origin of water quality, caused by rock-water interaction. This implies that the chemistry of the groundwater is controlled by geogenic process and not anthropogenic sources. None of the samples fall to Group II where $\mathrm{Na}^{+}+\mathrm{K}^{+}$and $\mathrm{Cl}^{-}+$ $\mathrm{SO}_{4}^{2-}$ over $\mathrm{Ca}^{2+}+\mathrm{Mg}^{2+}$ and $\mathrm{HCO}_{3}^{-}+\mathrm{CO}_{3}^{2-}$. The $\mathrm{HCO}_{3}^{-}$and $\mathrm{Cl}^{-}$distinguish between fresh and brackish water environments respectively.

\subsection{Hydrochemical Facies Characterization}

Hydrogeochemical facies describes the distribution and genesis of principal groundwater types (Back, 1960). The facies also provide information on progressive ion enrichment during stay of groundwater on the basis of residence time of water in subsurface and the extent of rock-water interaction (Subba Rao, 2017). The facies are arranged by taking the ionic percentages in relative decreasing order of their abundances. The facies can be classified with respect to residence time of water in aquifer material and topography as shown in Table 4. The water in the area is dominantly Type I-Recharge Water emanating from high topography.

The geochemical signatures/ratios are widely used to assess the origin of water as shown in Table 5. The $\mathrm{HCO}_{3}^{-}$is a dominant ion in groundwater, while $\mathrm{Cl}^{-}$is an abundant ion in seawater. The ratio of $\mathrm{HCO}_{3}^{-}$and $\mathrm{Cl}^{-}$is greater than 1 and implies Organic matter and/or $\mathrm{CO}_{2}$ or recharge area or upper water flow course of carbonate rocks (interaction of water with aquifer material). From the results 


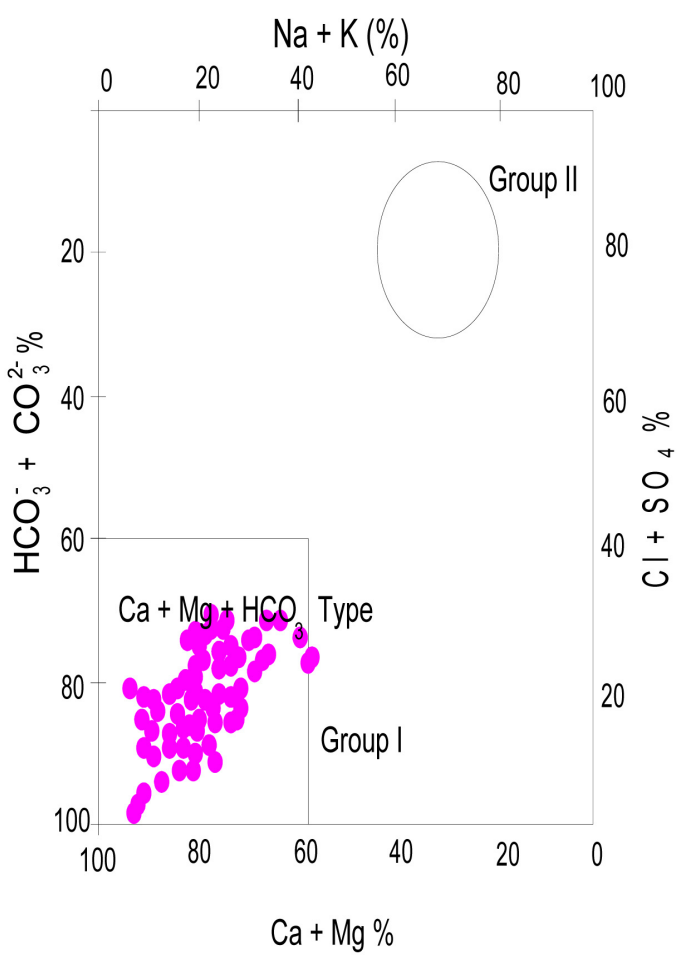

Figure 6. Evolution of groundwater quality of water samples showing prominent $\mathrm{Ca}^{2+}+$ $\mathrm{Mg}^{2+}+\mathrm{HCO}_{3}^{-}$type.

Table 4. Hydrochemical facies in relation to residence time of water and topography.

\begin{tabular}{cccc}
\hline Hydrogeochemical facies & Types & Water Type & Topography \\
\hline $\mathrm{Ca}^{2+}>\mathrm{Mg}^{2+}>\mathrm{Na}^{+}: \mathrm{HCO}_{3}^{-}+\mathrm{SO}_{4}^{2-}>\mathrm{Cl}^{-}$ & $\mathrm{I}$ & Recharge & High \\
$\mathrm{Mg}^{2+}>\mathrm{Ca}^{2+}>\mathrm{Na}^{+}: \mathrm{HCO}_{3}^{-}+\mathrm{CO}_{3}^{2-}>\mathrm{SO}_{4}^{2-}>\mathrm{Cl}^{-}$ & $\mathrm{I}$ & Recharge & High \\
$\mathrm{Na}^{+}>\mathrm{Mg}^{2+}>\mathrm{Ca}^{2+}: \mathrm{SO}_{4}^{2-}>\mathrm{Cl}^{-}>\mathrm{HCO}_{3}^{-}$ & II & - & - \\
$\mathrm{Na}^{+}>\mathrm{Mg}^{2+}>\mathrm{Ca}^{2+}: \mathrm{Cl}^{-}>\mathrm{SO}_{4}^{2-}>\mathrm{NO}_{3}^{-}>\mathrm{HCO}_{3}^{-}$ & III & - & - \\
$\mathrm{Na}^{+}>\mathrm{Mg}^{2+}>\mathrm{Ca}^{2+}: \mathrm{Cl}^{-}>\mathrm{SO}_{4}^{2-}>\mathrm{HCO}_{3}^{-}$ & IV & Discharge & Low \\
\hline
\end{tabular}

Table 5. Geochemical signatures (Subba Rao, 2017).

\begin{tabular}{|c|c|c|}
\hline GS & Range & Influence of \\
\hline \multirow[t]{3}{*}{$\mathrm{HCO}_{3}^{-}: \mathrm{Cl}^{-}$} & $>1.0$ & $\begin{array}{c}\text { Organic matter and/or } \mathrm{CO}_{2} \text { or recharge area or upper water flow } \\
\text { course of carbonate rocks }\end{array}$ \\
\hline & $<1.0$ & Lower water flow course of carbonate rocks \\
\hline & $<0.2$ & Saline water and brines \\
\hline \multirow[t]{4}{*}{$\mathrm{Na}^{+}: \mathrm{Cl}^{-}$} & 0.876 & Seawater \\
\hline & $<0.876$ & Replacement of $\mathrm{Na}^{+}$by $\mathrm{Ca}^{2+}$ or $\mathrm{Mg}^{2+}$ \\
\hline & $<0.7$ & Loss of $\mathrm{Na}^{+}$through precipitation of evaporate rocks \\
\hline & $>0.1$ & Waste flow through crystalline or volcanic rocks \\
\hline \multirow[t]{2}{*}{$\mathrm{Mg}^{2+}: \mathrm{Ca}^{2+}$} & $0.5-0.7$ & $\mathrm{CaCO}_{3}$ rocks \\
\hline & $0.7-0.9$ & $\mathrm{CaMg}\left(\mathrm{CO}_{3}\right)_{2}$ rocks \\
\hline
\end{tabular}




\section{Continued}

\begin{tabular}{|c|c|c|}
\hline & $>0.9$ & $\mathrm{Mg}^{2+}$ rich rocks or seawater mixture \\
\hline & $<0.5$ & $\mathrm{Ca}^{2+}$ rich water \\
\hline \multirow[t]{4}{*}{$\mathrm{Na}^{+}: \mathrm{K}^{+}$} & $15-25$ & Natural recharge area \\
\hline & $50-70$ & Lower water flow course \\
\hline & $>70$ & Volcanic rocks \\
\hline & $<15$ & $\mathrm{Na}^{+}$depleted water \\
\hline \multirow[t]{2}{*}{$\mathrm{Ca}^{2+}+\mathrm{Mg}^{2+}: \mathrm{Na}^{+}: \mathrm{K}^{+}$} & $>1.0$ & $\begin{array}{l}\text { Upper water flow course of carbonate rocks or precipitation of } \mathrm{NaCl} \\
\text { from brine or exchange of } \mathrm{Na}^{+} \text {and } \mathrm{K}^{+} \text {against } \mathrm{Ca}^{2+} \text { and/or } \mathrm{Mg}^{2+}\end{array}$ \\
\hline & $<1.0$ & Lower water flow course of carbonate rocks \\
\hline \multirow[t]{2}{*}{$\mathrm{Na}^{+}: \mathrm{Ca}^{2+}$} & $>1.0$ & Base ion exchange \\
\hline & $<1.0$ & Reverse ion exchange \\
\hline \multirow[t]{2}{*}{$\mathrm{Ca}^{2+}: \mathrm{SO}_{4}^{2-}+\mathrm{HCO}_{3}^{-}$} & $<1.0$ & Normal hydrological cycle \\
\hline & $>1.0$ & $\mathrm{Ca}^{2+}-\mathrm{Cl}^{-}$ \\
\hline
\end{tabular}

obtained, the $\mathrm{Na}^{+}: \mathrm{Cl}^{-}$is less than 0.7 signifying loss of $\mathrm{Na}^{+}$through precipitation of evaporate water; the water is $\mathrm{Ca}^{2+}$ rich and $\mathrm{Na}^{+}$depleted with $\mathrm{Mg}^{2+}: \mathrm{Ca}^{2+}$ less than 0.5 and $\mathrm{Na}^{+}: \mathrm{K}^{+}(<15)$ respectively. The $\mathrm{Na}^{+}: \mathrm{Ca}^{2+}(<1)$ indicates reverse ionic exchange. The $\mathrm{Ca}^{2+}: \mathrm{SO}_{4}^{2-}+\mathrm{HCO}_{3}^{-}$for the samples is less than 1.0 suggesting the flow of water through the normal hydrological cycle.

Chloro-alkaline indices (CA) is used in understanding the chemical composition of groundwater along its flow path. Subba Rao (2017) suggested two chloro-alkaline indices (CA1, CA2) for the interpretation of ion exchange between groundwater and host environment. A positive $\mathrm{CA}$ index indicates the exchange of $\mathrm{Na}^{+}$and $\mathrm{K}^{+}$from the water with $\mathrm{Mg}^{2+}$ and $\mathrm{Ca}^{2+}$ of the rocks, and is negative, when there is an exchange of $\mathrm{Mg}^{2+}$ and $\mathrm{Ca}^{2+}$ of the water with $\mathrm{Na}^{+}$and $\mathrm{K}^{+}$of the rocks. The CA indices are computed using Equation (2) and Equation (3).

$$
\begin{gathered}
\mathrm{CA} 1=\mathrm{Cl}^{-}-\mathrm{Na}^{+}+\mathrm{K}^{+}: \mathrm{Cl}^{-} \\
\mathrm{CA} 2=\mathrm{Cl}^{-}-\mathrm{Na}^{+}+\mathrm{K}^{+}: \mathrm{Cl}^{-}: \mathrm{SO}_{4}^{2-}+\mathrm{HCO}_{3}^{-}+\mathrm{NO}_{3}^{-}
\end{gathered}
$$

The groundwater samples show CA1 and CA2 in the range of -14.8 - 70.4 and $-0.56-1.05$. Only samples $33,34,35$, and 47 show negative values, confirming predominant cation-anion exchange reaction, in which ion exchange of $\mathrm{Na}^{+}$and $\mathrm{K}^{+}$from the water with $\mathrm{Mg}^{2+}$ and $\mathrm{Ca}^{2+}$ of the rocks.

\subsection{Groundwater Evaluation for Irrigation Purpose}

Excessive concentrations of dissolved ions in the irrigation water affects plants and agricultural soil physically and chemically through lowering osmotic pressure in the plant structural cells. Hence salinity hazard (C), sodium hazard, percent sodium $\left(\% \mathrm{Na}^{+}\right)$, permeability index (PI), residual sodium carbonate (RSC), magnesium ratio (MR) and Kelly ratio (KR) are widely used for the assessment of water quality for irrigation. 
The salinity hazard (C) is computed in terms of electrical conductivity. Figure 7 shows the spatial distribution of EC in the area. It shows a predominant range of $0-250 \mu \mathrm{S} / \mathrm{cm}$ (low salinity hazard) which covers about $80 \%$ of the area. This type of water is good for irrigation. The moderate-high salinity hazard water forms small closure especially in the northern part of the area. The high salinity hazard has less than $5 \%$ aerial dominance. The sodium hazard is computed in terms of sodium absorption ratio (SAR) as well as in terms of percent sodium $\left(\% \mathrm{Na}^{+}\right)$where the ions are expressed in meq/l using Equation (4) and Equation (5).

$$
\begin{gathered}
\mathrm{SAR}=\frac{\mathrm{Na}^{+}}{\sqrt{\frac{\mathrm{Ca}^{2+}+\mathrm{Mg}^{2+}}{2}}} \\
\% \mathrm{Na}^{+}=\frac{\left(\mathrm{Na}^{+}+\mathrm{K}^{+}\right)}{\left(\mathrm{Ca}^{2+}+\mathrm{Mg}^{2+}+\mathrm{Na}^{+}+\mathrm{K}^{+}\right)} \times 100
\end{gathered}
$$

The important chemical parameter for estimating the degree of suitability of water for irrigation as sodium content or alkali hazard for crops, which is expressed in sodium adsorption ratio (SAR). SAR is calculated from the ratio of sodium to calcium and magnesium. Calcium and magnesium ions are important since they are tending to counter the effect of sodium. Higher concentration of SAR leads to breakdown in the physical structure of the soil (Subba Rao et al., 2002). Sodium is adsorbed and become attached to soil particles. The soil then become hard and compact when dry and impervious to water penetration. Sodium replacing adsorb calcium and magnesium is a hazard as it causes damage to the soil structure. SAR of the studied water samples varies from 1.89 to 26.42 . The values are generally within $0-18$ specified by (Singh et al., 2015) as excellent

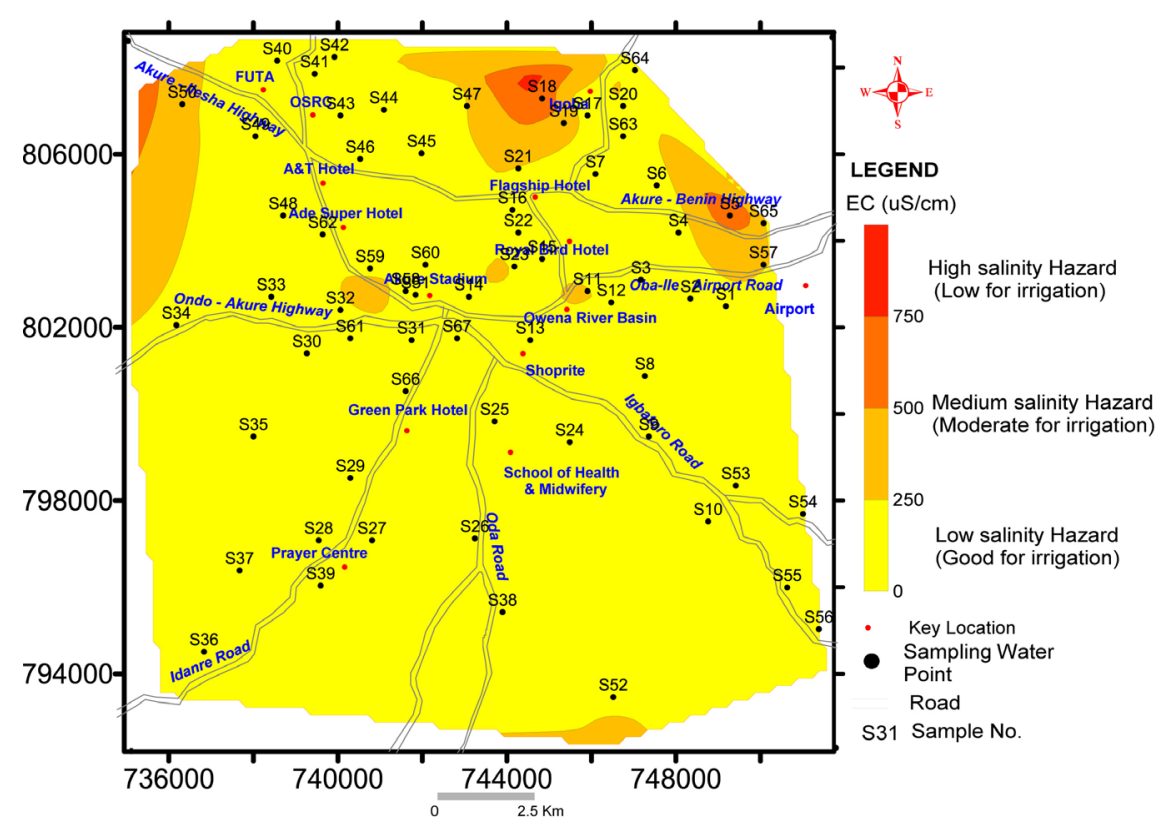

Figure 7. Spatial distribution of electrical conductivity (salinity hazard) in the study area. 
water for irrigation purpose (Figure 8). The $\% \mathrm{Na}^{+}$is inversely proportional to permeability of soils. The $\% \mathrm{Na}^{+}$obtained ranges from $0.41-3.45$ and the spatial distribution of $\% \mathrm{Na}^{+}$in Figure 9 shows dominant values in the range of $1.4-2.4$. In addition the Wilcox plot (Wilcox, 1955) of the water samples (Figure 10) shows "excellent to good" irrigation water.

Permeability is greatly influenced by $\mathrm{Na}^{+}, \mathrm{Ca}^{2+}, \mathrm{Mg}^{2+}, \mathrm{HCO}_{3}^{-}$and $\mathrm{Cl}^{-}$contents of the soil. It plays an important role in the growth of plants. If the permeability is low in the soil zone, it does not support plant growth. The degree of permeability condition in the soil is expressed in terms of permeability index (PI) computed using Equation (6). The concentrations of ions are expressed in meq/l.

$$
\mathrm{PI}=\frac{\mathrm{Na}^{+}+\sqrt{\mathrm{HCO}_{3}^{-}}}{\mathrm{Ca}^{2+}+\mathrm{Mg}^{2+}+\mathrm{Na}^{+}} \times 100
$$

The PI of the water samples varies from 42.67 to 170.24 . According to classification of PI in Table 6, the groundwater samples fall within "marginal-suitable" category, and from Figure 11(a), suitable irrigation area are widespread in the central zone. This area is also characterized by low values of RSC (less than 1.25). Residual sodium carbonate (RSC) is the difference between carbonates $\left(\mathrm{HCO}_{3}^{-}+\mathrm{CO}_{3}^{2-}\right)$ and alkaline earths $\left(\mathrm{Ca}^{2+}+\mathrm{Mg}^{2+}\right)$ which is expressed in meq/l. Carbonates have an effect on water quality through precipitation of alkaline earths, thereby increasing the $\%$ of $\mathrm{Na}^{+}$. This is more when the concentration of carbonates is in excess than that of alkaline earths. The excess carbonates combine with $\mathrm{Na}^{+}$to form $\mathrm{NaHCO}_{3}$, which affects soil structure. The RSC values

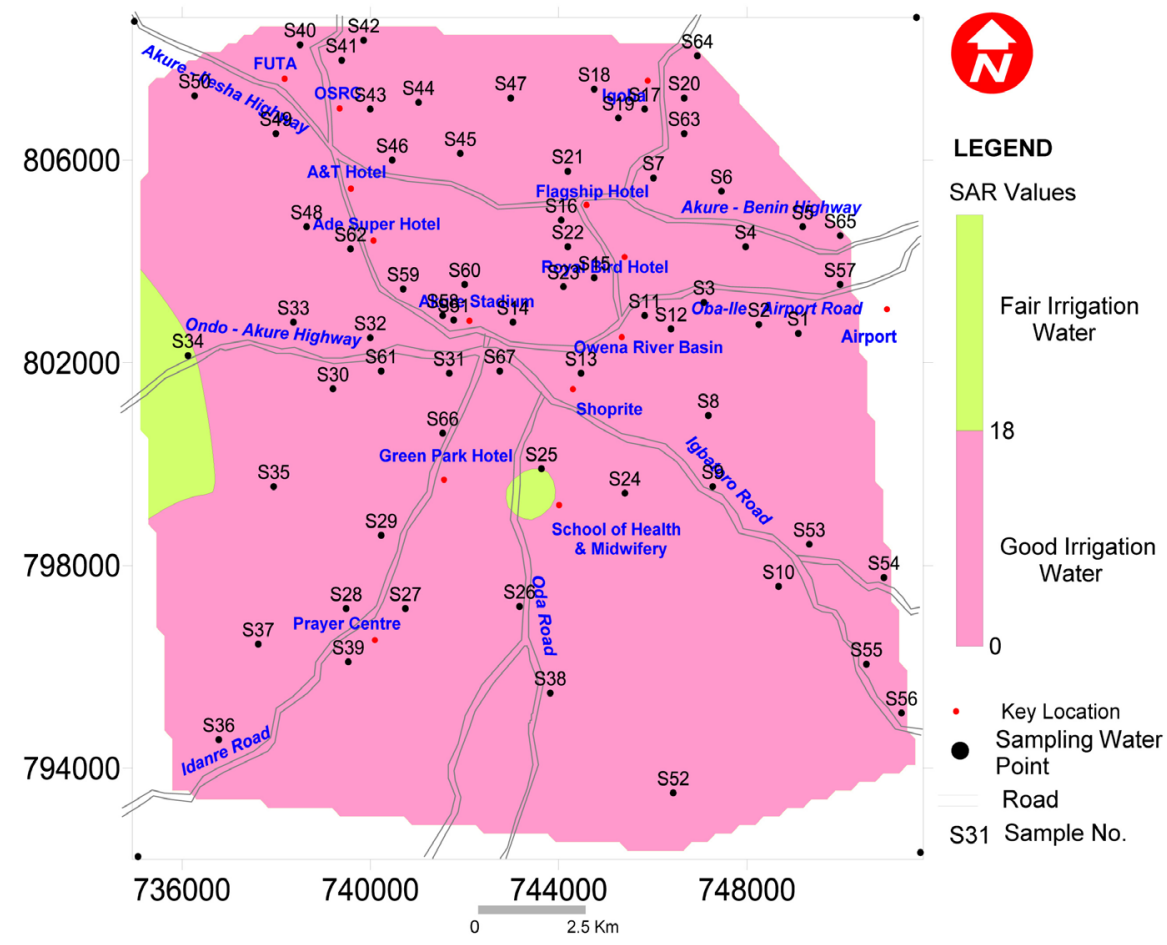

Figure 8. Spatial distribution of SAR. 


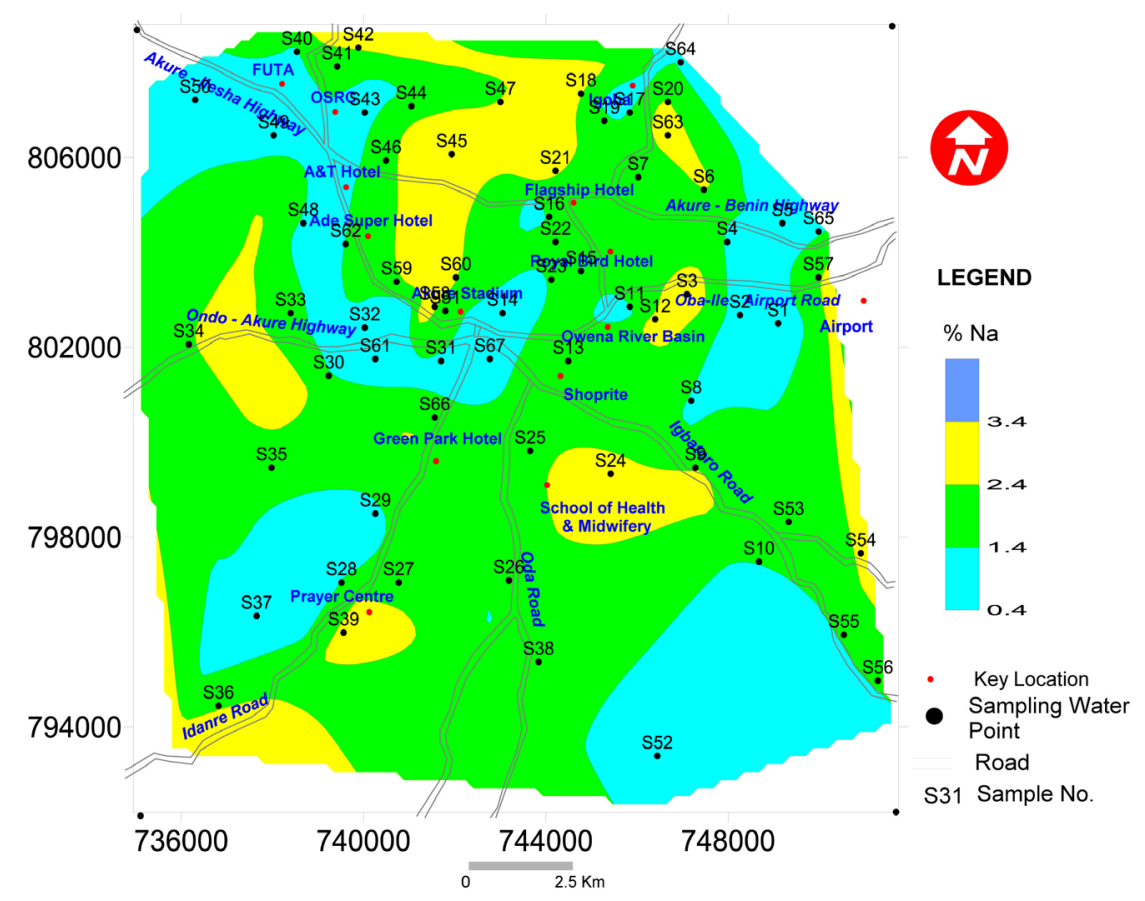

Figure 9. Spatial distribution of $\% \mathrm{Na}^{+}$in the study area.

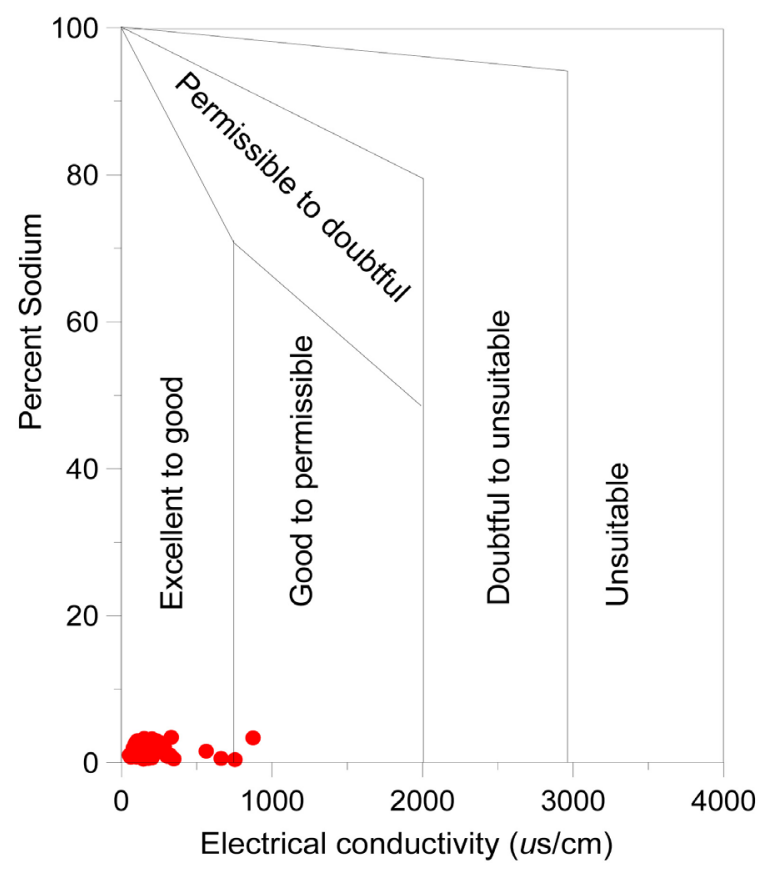

Figure 10. Wilcox's diagram for the water samples.

Table 6. Classification of PI for irrigation.

\begin{tabular}{ccc}
\hline Classification of PI & Permeability & Suitability \\
\hline 1 & Above $75 \%$ & Suitable \\
II & $25 \%$ to $75 \%$ & Marginal \\
III & Less than $25 \%$ & Unsuitable \\
\hline
\end{tabular}




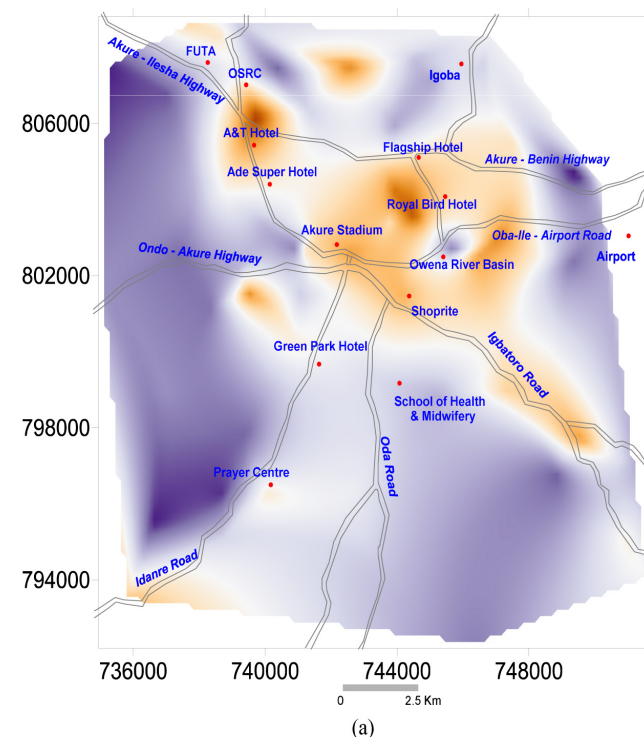

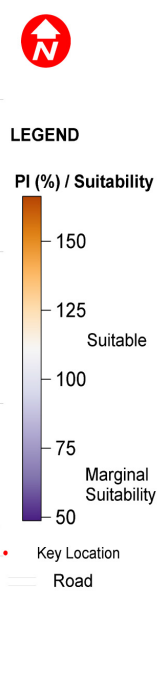

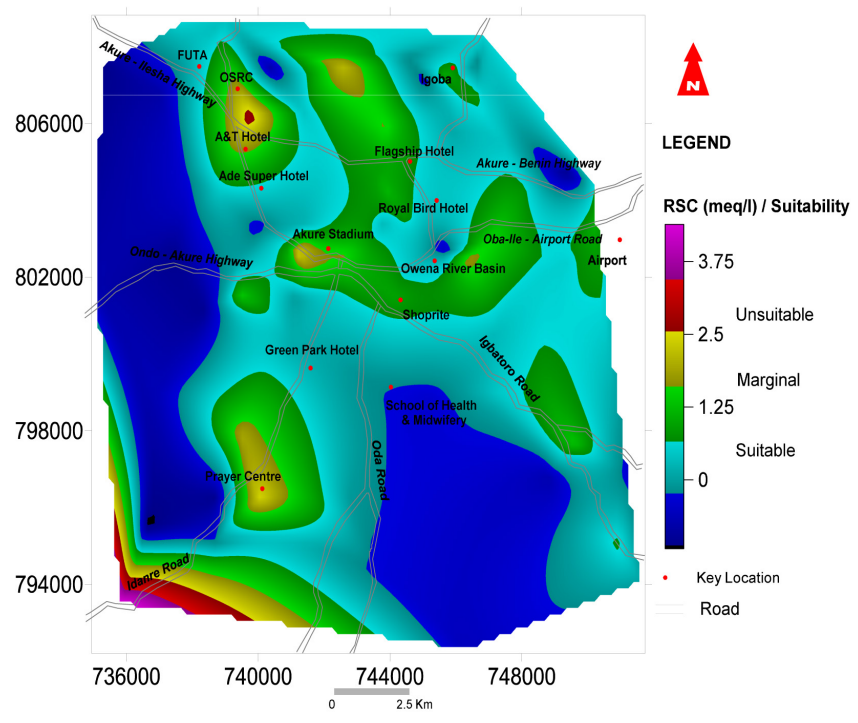

(b)

Figure 11. Spatial distribution of: (a) PI and (b) RSC.

range between -1 to 5 . Spatial distribution of RSC in the study area shows very high RSC (>2.5) in the southwest (Figure 11(b)). However the irrigation water quality in the area is generally "marginal/suitable" (Table 7). Magnesium ratio (MR) is the ratio of magnesium $\left(\mathrm{Mg}^{2+}\right)$ to alkaline earths $\left(\mathrm{Ca}^{2+}+\mathrm{Mg}^{2+}\right)$ and expressed in percentage (\%). Magnesium damages soil structure, when water possesses more $\mathrm{Na}^{+}$and high salinity.

In equilibrium more $\mathrm{Mg}^{2+}$ can affect soil quality by rendering it alkaline, thus it affects crop yields (Collins \& Jenkins, 1996). The MR of the water samples varies from 4 to 53 . The values of MR progressively increase radially from the central part of the study area (Figure 12).

Kelly ratio (KR) is used to classify the irrigation water quality, which is the level of $\mathrm{Na}^{+}$measured against $\mathrm{Ca}^{2+}$ and $\mathrm{Mg}^{2+}$, where the concentrations of ions are in meq/l. If the KR is less than one, it is suitable for irrigation, and if it is more than one, it is unsuitable (Table 7). The KR values calculated for the water samples are in between 0.04 and 0.84 . Figure 12 shows that area with high values of KR have high MR and vice versa.

\section{Conclusion}

Hydrochemical facies characterization and groundwater quality evaluation of Akure, Ondo State, Nigeria have been studied. The $\mathrm{pH}$ and Eh of the water samples show an acidic condition. Generally the water in the study area falls within zone 5 which comes under carbonate hardness or fresh water type. They are characterized by $\mathrm{Ca}^{2+}$ and $\mathrm{Mg}^{2+}$ of $\mathrm{HCO}_{3}^{-}$and $\mathrm{CO}_{3}^{2-}$ over $\mathrm{Na}^{+}$and $\mathrm{K}^{+}$of $\mathrm{Cl}^{-}$ and $\mathrm{SO}_{4}^{2-}$. Only few samples (about $5 \%$ ) belong to mixed type (transition zone) where no cation-anion pair exceeds $50 \%$. The chemistry of the water falls in the precipitation domain, indication a meteoric origin. Hence the rock-water interaction is responsible for the source of dissolved ions (geogenic origin). 
Table 7. Classification of RSC, MR, and KR for irrigation [14].

\begin{tabular}{cc}
\hline RSC $(\mathrm{meq} / \mathrm{l})$ & Suitability \\
$<1.25$ & Suitable \\
$1.25-2.50$ & Marginal \\
$>2.50$ & Unsuitable \\
$\mathrm{MR}$ & \\
$>50$ & Suitable \\
$<50$ & Unsuitable \\
$\mathrm{KR}$ & \\
$>1.0$ & Good \\
$<1.0$ & Not Good \\
\hline
\end{tabular}

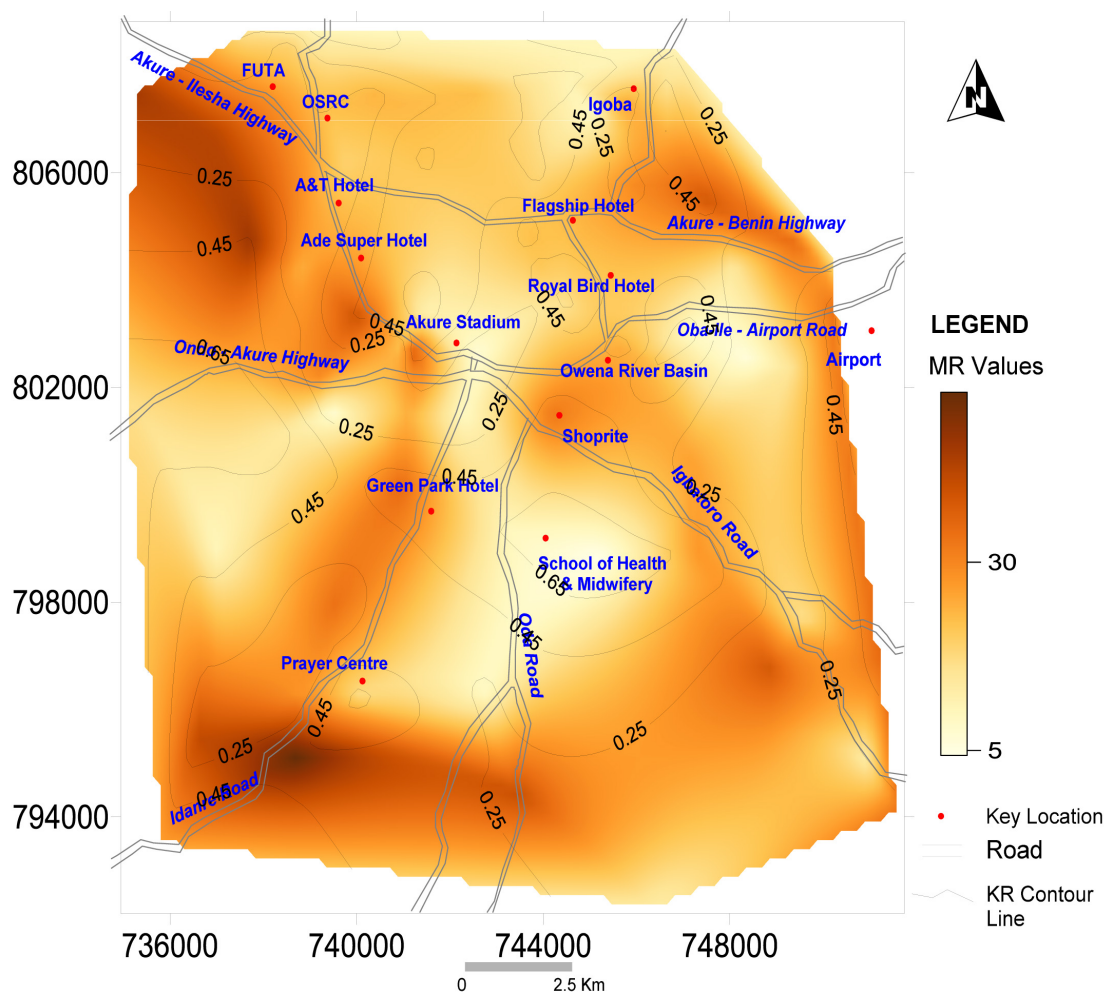

Figure 12. Spatial distribution of MR and KR.

The geochemical signatures show $\mathrm{Na}^{+}: \mathrm{Cl}^{-}$is less than 0.7 signifying loss of $\mathrm{Na}^{+}$ through precipitation of evaporate water; the water is $\mathrm{Ca}^{2+}$ rich and $\mathrm{Na}^{+}$depleted with $\mathrm{Mg}^{2+}: \mathrm{Ca}^{2+}$ less than 0.5 and $\mathrm{Na}^{+}: \mathrm{K}^{+}(<15)$ respectively. The $\mathrm{Na}^{+}: \mathrm{Ca}^{2+}(<1)$ indicates reverse exchange. The major ion chemistry data revealed that the ground water in the study area is fresh in nature. The $\mathrm{Ca}^{2+}: \mathrm{SO}_{4}^{2-}+\mathrm{HCO}_{3}^{-}$for the samples is less than 1.0 suggesting the flow of water through the normal hydrological cycle. The water in the area is dominantly Type I-Recharge Water emanating from high topography. Chloro-alkaline indices (CA) confirms predominant cation-anion exchange reaction, in which ion exchange of $\mathrm{Na}^{+}$and $\mathrm{K}^{+}$ 
from the water with $\mathrm{Mg}^{2+}$ and $\mathrm{Ca}^{2+}$ of the rocks of $0-250 \mu \mathrm{S} / \mathrm{cm}$ (low salinity hazard) covers about $80 \%$ of the area. Based on the classification of irrigation water according to SAR, PI, RSC, MR, KR, \%Na values, all the sample locations are generally suitable for irrigation purposes. In addition, based on the Wilcox classification, $1 \%$ of the water samples belong to good to permissible category for irrigation use due to the presence of excess sodium salts that cause deflocculating and reduce the permeability of soil.

\section{Acknowledgements}

The authors are grateful to Federal Water Resources, Akure for assistance rendered during analysis. More thanks go to TET Fund, through the Centre for Research and Development, Rufus Giwa Polytechnic, Owo, Ondo State, Nigeria for providing the grants for the study.

\section{Conflicts of Interest}

The authors declare that no conflict of interest exists.

\section{References}

Alam, M., Rais, S., \& Aslam, M. (2012). Hydrochemical Investigation and Quality Assessment of Ground Water in Rural Areas of Delhi, India. Environmental Earth Sciences, 66, 97-110. https://doi.org/10.1007/s12665-011-1210-X

Aniya, F. B., \& Shoeneick, K. (1992). Hydrogeological Investigation of the Aquifer of Bauchi Area. Journal of Mining and Geology, 28, 45-53.

Back, W. (1960). Origin of Hydrochemical Facies in Groundwater in the Atlantic Coastal Plain.

Backman, B., Bodis, D., Lahermo, P., Rapant, S., \& Tarvainen, T. (1998). Application of a Groundwater Contamination Index in Finland and Slovakia. Environmental Geology, 36, 55-64. https://doi.org/10.1007/s002540050320

Bayode, S., Ojo, J. S., \& Olorunfemi, M. O. (2006). Geoelectric Characterization of Aquifer Types in the Basement Complex Terrain of Pats of Osun State, Nigeria. Global Journal of Pure and Applied Sciences, 12, 377-385. https://doi.org/10.4314/gjpas.v12i3.16623

Collins, R., \& Jenkins, A. (1996). The Impact of Agricultural Land Use on Stream Chemistry in the Middle Hills of the Himalayas, Nepal. Journal of Hydrology, 185, 71-86. https://doi.org/10.1016/0022-1694(95)03008-5

Coulibaly, H., \& Rodriguez, M. J. (2004). Development of Performance Indicators for Quebec Small Water Utilities. Journal of Environmental Management, 73, 243-255. https://doi.org/10.1016/j.jenvman.2004.07.003

Domenico, P. A., \& Schwartz, F. W. (1990). Physical and Chemical Hydrogeology (p. 824). New York: John Wiley \& Sons.

Driscoll, F. G. (1986). Groundwater and Wells. St. Paul, MN: Johnson Division.

Fetter, C. W. (1983). Contaminant Hydrogeology. New York: Macmillan Publishing Co.

Fetter, C. W. (1990). Applied Hydrogeology (2nd ed., 592 p.). New Delhi: CBS Publisher \& Distributor.

Fetter, C. W. (1993). Contaminant Hydrology. New York: Macmillan Pub. Co. 
Freeze, R. A., \& Cherry, J. A. (1979). Groundwater (604 p.). Englewood Cliffs, NJ: Prentice-Hall.

Gibb, J. P., Schuller, R. M., \& Griffin, R. A. (1981). Procedures for the Collection of Representative Water Quality Data from Monitoring Wells. Cooperative Groundwater Report No. 7, Champaign, IL: Illinois State Water Survey and Illinois State Geological Survey.

Hem, J. D. (1989). Study and Interpretation of the Chemical Characteristics of Natural Waters (3rd ed.). U.S. Geological Survey Water Supply Paper 2254.

Jain, C. K., Bandyopadhyay, A., \& Bhadra, A. (2010). Assessment of Ground Water Quality for Drinking Purpose, District Nainital, Uttarakhand, India. Environmental Monitoring and Assessment, 166, 663-676. https://doi.org/10.1007/s10661-009-1031-5

Lloyd, B., \& Helmer, R. (1991). Surveillance of Drinking Water Quality in Rural Areas (171 p.). Published for WHO/UNEP, Harlow: Longmans Scientific and Technical.

Matthess, G. (1982). The Properties of Groundwater (406 p.). New York: J. Wiley.

Ojo, J. S., Olorunfemi, M. O., Aduwo, I. A., Bayode, S., Akintorinwa, O. J., Omosuyi, G. O., \& Akinluyi, F. O. (2014). Assessment of Surface and Groundwater Quality of the Akure Metropolis, Southwestern Nigeria. Journal of Environment and Earth Science, 4, $19 \mathrm{p}$.

Parker, J. M., \& Foster, S. S. D. (1986). Groundwater Monitoring for Early Warning of Diffuse Pollution. In D. Lemer (Ed.), Monitoring to Detect Changes in Water Quality Series (pp. 37-46). Proceedings of the Budapest Symposium, IAHS Publication No. 157, Wallingford: International Association of Hydrological Sciences.

Piper, A. M. (1944). A Graphic Procedure in the Geochemical Interpretation of Water Analysis. Transactions, American Geophysical Union, 25, 914-923. https://doi.org/10.1029/TR025i006p00914

Price, M. (1985). Introducing Groundwater (195 p). London: George Allen and Unwin.

Raju, N. J. (2012). Evaluation of Hydrogeochemical Processes in the Pleistocene Aquifers of Middle Ganga Plain, Uttar Pradesh, India. Environmental Earth Sciences, 65, 1291-1308. https://doi.org/10.1007/s12665-011-1377-1

Raju, N. J., Ram, P., \& Dey, S. (2009). Groundwater Quality in the Lower Varuna River Basin, Varanasi District, Uttar Pradesh, India. Journal of the Geological Society of India, 7, 178-192. https://doi.org/10.1007/s12040-008-0048-4

Raju, N. J., Shukla, U. K., \& Ram, P. (2011). Hydrogeochemistry for the Assessment of Groundwater Quality in Varanasi: A Fast-Urbanizing Center in Uttar Pradesh, India. Environmental Monitoring and Assessment, 173, 279-300. https://doi.org/10.1007/s10661-010-1387-6

Satheesh, B., Sateesh, S., Kumar, K., \& Reddy, N. (2017). Assessment of Groundwater Quality for Irrigation Use and Evolution of Hydrochemeical Facies in the Yeshwanthapur Sub-Basin, Warangal Dist. IOSR Journal of Applied Geology and Geophysics, 5, 14-20. https://doi.org/10.9790/0990-0504011420

Scalf, M. R., McNabb, J. F., Dunlap, W. F., Cosby, R. L., \& Fryberger, J. (1981). Manual of Groundwater Sampling Procedures (93 p.). Worthington, OH: National Water Well Association.

Shitta, K. A. (2007). Lithostratigraphy of Nigeria-An Overview. In Proceedings, Thirty-Second Workshop on Geothermal Reservoir Engineering Stanford University (SGP-TR-183).

Siddiqui, A., Naseem, S., \& Jalil, T. (2005). Groundwater Quality Assessment in and around Kalu Khuhar, Super Highway, Sindh, Pakistan. Journal of Applied Sciences, 5, 
1260-1265. https://doi.org/10.3923/jas.2005.1260.1265

Singh, S., Raju, N. J., \& Ramakrishna, Ch. (2015). Evaluation of Groundwater Quality and Its Suitability for Domestic and Irrigation Use in Parts of the Chandauli-Varanasi Region, Uttar Pradesh, India. Journal of Water Resource and Protection, 7, 572-587. https://doi.org/10.4236/jwarp.2015.77046

Srinivasamoorthy, K., Chidambaram, M., Prasanna, M. V., Vasanthavigar, M., Peter, J., \& Anandhan, P. (2008). Identification of Major Sources Controlling Groundwater Chemistry from a Hard Rock Terrain-A Case Study from Mettur Taluk, Salem District, Tamilnadu, India. Journal of Earth System Sciences, 117, 49-58.

https://doi.org/10.1007/s12040-008-0012-3

Subba Rao, N. (2017). Hydrogeology-Problems with Solutions (265 p.). Delhi: PHI Learning Private Limited.

Subba Rao, N., Prakasa Rao, J., John Devadas, D., Srinivasa Rao, K. V., Krishna, C., \& Nagamalleswara Rao, B. (2002). Hydrogeochemistry and Groundwater Quality in a Developing Urban Environment of a Semi-Arid Region, Guntur, Andhra Pradesh, India. Journal of the Geological Society of India, 59, 159-166.

Thomson, J. A. M., \& Foster, S. S. D. (1986). Effect of Urbanisation on Groundwater of Limestone Islands: An Analysis of the Bermuda Case. Journal of Institute of Water Engineering Science, 40, 527-540.

Todd, D. K. (1980). Groundwater Hydrology (2nd ed., 535 p.). New York: John Wiley.

Vasanthavigar, M., Srinivasamoorthy, K., Vijayaragavan, K., Rajiv Ganthi, R., Chidambaram, S., Anandhan, P., Mani vannan, R., \& Vasudevan, S. (2010). Application of Water Quality Index for Groundwater Quality Assessment: Thirumanimuttar Sub-Basin, Tamilnadu, India. Environmental Monitoring and Assessment, 171, 595-609.

https://doi.org/10.1007/s10661-009-1302-1

Wilcox, L. V. (1955). Classification and Use of Irrigation Water (Circular No. 969, p. 19). Washington DC: U.S. Geological Survey Department of Agriculture. 